\title{
Corporate Social Responsibility in Vietnam: Systematic Review of Research and Future Directions
}

\begin{tabular}{|r|l|}
\hline Journal: & Society and Business Review \\
\hline Manuscript ID & SBR-09-2020-0114.R3 \\
\hline Manuscript Type: & Literature Review \\
\hline Keywords: & $\begin{array}{l}\text { Corporate social responsibility, CSR research, systematic review, } \\
\text { context, Vietnam }\end{array}$ \\
\hline
\end{tabular}

\section{SCHOLARONE $^{\text {M }}$ \\ Manuscripts}




\title{
Corporate Social Responsibility in Vietnam: Systematic Review of Research and Future Directions
}

\begin{abstract}
While research on corporate social responsibility (CSR) is reaching new territories, the extent to which such literature manifests itself in developing countries is yet to be fully understood. To that end, this study investigates the understanding, evolution, and practice of CSR in Vietnam. A systematic review of the current literature in the recent past (2000-2020) has been embraced in this research. By analysing a total of 143 articles, we demonstrate that there has been visible growth in published articles related to CSR in Vietnam over the last 21 years. However, the most significant gap in the existing literature is the lack of context-sensitive studies. This study is not only the first to provide an enhanced overview of the current state of CSR knowledge in the country but also sets out directions within the CSR research agenda related to Vietnam and potentially other emerging and developing countries.
\end{abstract}

Keywords

Corporate social responsibility; CSR research; Vietnam; systematic review; context. 


\section{Introduction}

The origins of corporate social responsibility (CSR) have been widely attributed to scholars in the West, and the concept of CSR has become a sub-field of management and organisation studies in its own right (Crane \& Matten, 2021; Lockett, Moon, \& Visser, 2006; Lortie \& Cox, 2018). Various reviews of CSR scholarship have been published (such as Akbari \& McClelland, 2020; Amos, 2018; Bass \& Milosevic, 2016; Jamali \& Karam, 2016; Velte, 2021), and the insights drawn from these articles have identified two main elements in CSR scholarship. First, CSR literature remains highly fractured, and there is currently no universally accepted definition of CSR (Bass \& Milosevic, 2016; Schneider, 2020). Secondly, CSR literature has traditionally been associated with 'Western assumptive logics', centralising the predominance of market-based forms of organisation in liberal market economies that are typically supported through coherent systems of governance, strong regulatory oversight, and enforcement of contractual rights (Amos, 2018; Jamali \& Karam, 2016; Karimova \& Goby, 2021; Khan, Lockhart, \& Bathurst, 2021; Tilt, 2016).

Since the turn of the millennium over 20 years ago, the literature on CSR has become more complex and multifaceted. In particular, there has been a shift in focus towards the context-dependence nature of CSR. Pioneering contributions that have refocused the discussion on the importance of context in relation to CSR research include Campbell (2007) and Matten and Moon (2008). They proposed that contextual variation across countries, such as institutional frameworks or national business system configurations, may ultimately influence CSR conceptualization (CSR Thinking) and CSR implementation (CSR Doing). Their arguments are strongly supported by empirical CSR studies in developing countries, especially in Asia (Khan \& Sulaiman, 2021; S. B. Choi, Feng, Liu, \& Zhu, 2019; Dzever \& Gupta, 2012; C. H. Kim, Amaeshi, Harris, \& Suh, 2013; Yu, Ding, \& Chung, 2015). These articles not only suggest that Western values, laws, and free-market conditions do not always accord with the Asian context but also show that CSR in Asia has distinctive features due to institutional constellations such as local socio-cultural values and traditions (Khan et al., 2021; Murphy \& Smolarski, 2020; Wang \& Juslin, 2009), levels of economic development (Conte, Vollero, Covucci, \& Siano, 2020; Hong \& Kim, 2017), and political system and governance (Rauf, Voinea, Bin Azam Hashmi, \& Fratostiteanu, 2020; Khan, Lockhart \& Bathurst, 2018).

Still, CSR studies face many challenges in addressing the complexity and fluidity of the Asian context. Given the pressures of globalisation and the expected harmonisation of management practices across cultures, there are many arguments that all organisations should apply the same CSR practice regardless of cultures, religions, and nations (Mazboudi, Sidani, \& Al Ariss, 2020). Moreover, there are also weaknesses in how context 
has been conceptualised and empirically explored. Davidson (2016), for example, asserts that much of the CSR research tends to underplay the role of context, treating it as background noise rather than an essential part of the problem. In agreement with this, Tilt (2016) questioned the transferability of frameworks and conclusions drawn in the advanced world to different institutional settings, calling for a more nuanced analysis of CSR manifestations. Hence, the need for country studies focused on CSR in Asia becomes particularly critical (Khan, Sulaiman, Nazir, \& Ahmad, 2020; Amos, 2018; Jamali \& Karam, 2016 Khan, Lockhart \& Bathurst, 2020).

In light of the above observations, we seek to obtain an overview of the intellectual structure of this emerging field of research in a developing country. Vietnam is selected as a novel national context for this study because it provides a wholly different environment for CSR. Vietnam is a nation with a distinctive history and cultural admixture. Given its complicated national history - the millennium of Chinese domination alongside the French and American interventions, there is a mixture of Western and Eastern philosophies and a blend of capitalist and socialist values in Vietnam. The rich and complex social and cultural aspects of Vietnam and its heritage of substantial values along with its contemporary, transitional economy consequently reflect not only a context of grand challenges (Ferraro, Etzion, \& Gehman, 2015) but also highlight research opportunities to explore CSR in their distinctive and special milieu. However, thus far, insights into the nature and development of CSR knowledge in Vietnam have been scarce (M. Nguyen, Bensemann, \& Kelly, 2018). Hence, this article concentrates on dissecting and resolving knowledge gaps of the status of CSR in Vietnam in the recent past (2000-2020) and future research trends by explicitly attempting to answer the following questions:

RQ1. How has the state of scholarly research on CSR in Vietnam changed over the past 20 years?

$R Q 2$. What are the different types of research methodologies and data analysis adopted to evaluate CSR in Vietnam?

RQ3. What are the motivating research directions for future researchers in CSR in Vietnam?

Answers to the research questions will provide useful insights for researchers interested in CSR in Vietnam by providing a comprehensive clarification of what has been published by accredited scholars and indicating possible gaps in the literature and future direction. There is also a lack of a comprehensive literature review investigating and analysing CSR in a South-East Asian country. Therefore, our literature review contributes to addressing the complexities of the Asian context to understand better the opportunities and limitations of the academic progress achieved in this research field. In the following sections, we describe the methods used to generate our list of journal articles. We also discuss the main elements of our analysis and the 
methods we used. The results section contains an extensive analysis of these data, using various bibliometric procedures. Finally, the discussion section presents a five-stage map of CSR development in the Vietnamese context, followed by a discussion on theoretical and methodological directions for future research, which is of potential interest to CSR researchers, policymakers, and managers in Vietnam.

\section{Methodology}

\subsection{Defining CSR}

It is widely accepted that there is no universally accepted definition of CSR, which is therefore given disparate interpretations among scholars. To avoid confusion, for this article, we start with an umbrella idea that CSR captures the variety of ways in which the business-society relationship is defined, managed, and practised (Frynas \& Yamahaki, 2016). More specifically, we adopt Blowfield and Frynas (2005)'s definition of CSR as 'a responsibility: (a) for their impact on society and the natural environment, sometimes beyond legal compliance and the liability of individuals; (b) for the behaviour of others with whom they do business (e.g., within the supply chains); and (c) to manage their relationship with the wider society, whether for reasons of commercial viability or to add value to society' (Blowfield \& Frynas, 2005, p. 503). This approach is in line with the 'progressive view' that an organisation is organised for the interest of society at large or at least has fiduciary responsibilities that extend to a wide variety of stakeholders.

\subsection{Prelude to literature review}

Since the turn of the millennium over 20 years ago, Western and Vietnamese scholars have increasingly paid attention to CSR in Vietnam (such as Han, 2016; Huang, Do, \& Kumar, 2019; Hieu Thanh Nguyen, Hoang, \& Luu, 2019; Tran \& Jeppesen, 2016; Van \& Nguyen, 2019). To a certain extent, CSR research should be reflective of the development of CSR in Vietnam. To date, however, the literature has proliferated without any attempt to examine whether or not CSR research in Vietnam has appropriately reflected the peculiarities of the Vietnamese context. Motivated by this gap, we amalgamate the literature on CSR in Vietnam in a systematic approach, generally contemplated as 'a specific methodology that locates existing studies selection and contribution, analysis and synthesizes data, and reports the evidence in such a way that allows reasonable, clear conclusions to be reached about what is and is not known' (Denyer \& Tranfield, 2009, p. 671).

Systematic literature reviews may serve several objectives. For instance, such a review may contribute towards assessing the influence of different journals (Amos, 2018; Lockett et al., 2006) to obtain an overview of the intellectual structure of a field of research (Akbari \& McClelland, 2020; Moon \& Shen, 2010; Pisani, Kourula, Kolk, \& Meijer, 2017), or to suggest the path to theoretical advancement in a field of research (T. H. Lee, 2017; 
Taneja, Taneja, \& Gupta, 2011; Zanfardini, Aguirre, \& Tamagni, 2016). In this study, we argue that embarking on a literature review is an important foundation for examining, appraising, and mapping the understanding, evolution, and practice of CSR in Vietnam. Therefore, the review methods we deploy aim to obtain the intellectual structure of CSR in Vietnam research. It should also be noted that the translation of literature review research evidence is not always straightforward as it is of paramount importance that the construction, dissemination and the overall nature of research, knowledge obtained, strategy, policy and practice are aligned together (Seuring \& Müller, 2008; Winter \& Knemeyer, 2013).

\subsection{Strategy of our review}

In general terms, systematic literature reviews are grounded on a set of common underlying principles, which implies that such reviews may be guided by varying research questions and systematic approaches (Amos, 2018). In this study, given the scope of social science publications in Vietnam, instead of a quantitative meta-analysis, a qualitative systematic review has been embraced in this research to provide an in-depth evaluation of previous research. Following the methodological advice of Lockett et al. (2006) and Taneja et al. (2011), we structured our review in five steps, as illustrated in Figure 1.

\section{INSERT FIGURE 1 HERE}

\subsection{Selection of journal articles}

The five steps are explained in more detail below.

Step 1. We identified the scheme of the literature review in terms of keywords/phrases, time period, and data sources. Specifically, the collection of literature for this research has been based on the following criteria:

Data sources. We systematically searched for peer-reviewed journal articles related to CSR in Vietnam using three prominent databases in business and management: Web of Science (Clarivate Analytics), Scopus, and The Business Source Premier (EBSCO). These electronic databases provided quality because the top-ranked management journals publishing on management research and specialised journals publishing on CSR research were included. They also ensured quantity, as these electronic databases comprise more than one million articles in management and social science research. The selection of databases is consistent with Lockett et al.'s (2006) suggestion that CSR can be regarded as an applied management topic.

Search terms. Next, we narrowed the searches by resorting to the root search string "corporate social responsibility" AND "Vietnam*" in the title, topic, or abstract.

Time period. Following the introduction of the new Company law in 1999 that reduced entry barriers and signalled a shift in the country's economic reform, Vietnam has witnessed a significant shift in society since 
2000 (Malesky \& Taussig, 2017; M. Nguyen et al., 2018). The years 2000-2020 have accordingly been covered in the review and analyses.

Step 2. The initial search in the electronic databases resulted in 346 articles. Upon scrutinizing the articles, we detected that duplication of journal articles in these databases had substantially increased the number. All articles were then double-checked, and this resulted in 223 articles excluding duplicates, in which 129 articles were from Scopus, 56 were from Web of Science, and 38 were from EBSCO.

Step 3. An extensive bibliographic analysis of the 223 papers was undertaken and independently categorised by authors, year of publication, source (name of journals), title and abstract, and research areas (industry).

Step 4. The title and abstract of all publications were screened independently by the authors to ensure they referred to CSR in Vietnam. To be selected, the study also needs to be published in a language accessible to the reviewers. The screening process resulted in the exclusion of 42 articles, mainly because they did not meet our selection criteria or the study's objectives.

Step 5. The selection process was further refined to determine the number of articles to be reviewed. For an article to be selected, it had to be a full text. The whole process resulted in a final sample of 143 articles for analysis.

A flow chart of reviewed articles following the PRISMA 2009 guidelines is presented in Figure 2.

\section{INSERT FIGURE 2 HERE}

\subsection{Content analysis}

All 143 articles were read and coded independently by the authors in the analysis phase, using NVIVO and Microsoft Excel. For purposes of coding, each article was coded in terms of knowledge type and research focus, as illustrated in Figure 3. According to Lockett et al. (2006) and Moon and Shen (2010), the knowledge type of the articles were classified as (a) theoretical or empirical; (b) if it was theoretical, whether it was normative (concerned with 'oughts' and 'shoulds') or non-normative (concerned with 'hows' and 'whys'); and (c) if it was empirical, whether it was quantitative, qualitative, or a mixed method. Although there is no strict dichotomy between empirical and theoretical research, we intended to identify the main contribution from each article. In terms of research focus, we categorized articles according to the scope and design of the research in the articles, following the categorizations from Orlikowski and Baroudi (1991) and Chen and Hirschheim (2004). Specifically, we used three categorical tools to assess the scope: (i) dominant CSR theme, (ii) key research objectives, and (iii) 
theoretical perspectives on CSR in Vietnam, and three tools to assess the research design of the selected articles: (iv) methodological review, (v) sources and nature of data, and (vi) data testing and analysis.

\section{INSERT FIGURE 3 HERE}

The process of content analysis was primarily based on the judgement of the authors who separately classified each paper. To establish reliability, a joint revision was undertaken to check for consistency. In the few cases (less than 5 per cent) where doubts or differences of opinion initially occurred, these were resolved through further joint scrutiny of the respective papers. In this way, elements of subjective bias were minimized.

\section{Results}

\subsection{Distribution by year}

Timeline analysis of the 143 published papers is represented in Figure 4. Despite its introduction to Vietnam in the early 2000s, analysis of the data collected shows that no articles were found in the first five years from 2000 to 2004. Only four articles about CSR in Vietnam were published from 2005 to 2011. This tendency may indicate that CSR in Vietnam was a specialist sub-field in the literature during this period (from 2000 to 2011). By comparison, 73 CSR articles were published in China between 1993 to 2007 (Moon \& Shen, 2010). Figure 4 also reveals a growing trend after 2011, with 19 articles published between 2012 and 2015 and a continuous increase of publications in the later years, totalling 120 articles published in the most recent years, from 2016 to 2020 . In general, nearly 85 per cent of articles were published over the last five years: 2016 (12 articles), 2017 (13 articles), 2018 (18 articles), 2019 (22 articles), and 2020 (55 articles). Despite an uncertain trough in publications in 2014 , the data authenticates a stable and growing interest among researchers in the concept of CSR in Vietnam, which could be explained by an accelerated change in public perceptions over the role of business in relation to social needs and goals. Extreme socially disruptive events like COVID-19 may have further contributed to the overall trend in the growth of published papers focusing on CSR in Vietnam, with a peak in the number of publications in 2020. This trend consequently predicts a long-term development of CSR in Vietnam in the upcoming years.

\section{INSERT FIGURE 4 HERE}

\subsection{Distribution by journals}

Overall, 83 international journals have served as outlets through which CSR research focused on Vietnam have been published in the studied period (2000-2020). Table 1 shows the list of journals, indicating that Sustainability published the greatest number of papers (12). This is followed by the Journal of Asian Finance, Economics and Business (11), Management Science Letters (11), Journal of Cleaner Production (6), Journal of Business Ethics (5), Journal of Sustainable Tourism (4), Accounting (3), Corporate Social Responsibility and Environment 
Management (3), and Social Responsibility Journal (3). 11 of the journals published two papers each, while the remaining 63 journals published one paper each. In terms of content, these journals can be divided into five main subject categories: (A) Sustainability and CSR (42 articles); (B) International Business, Economics \& Finance (31); (C) Management and Organizational studies (38); (D) Other-specific management fields (21); (E) Marketing \& Communication (11). Although most articles were published in journals related to sustainability and CSR, our results suggest that CSR in Vietnam research also covers multiple research areas, indicating multi-disciplinary perspectives on the topic. The data also highlights the contribution of quality journals to the CSR in Vietnam literature and supports practitioners and researchers in different discipline areas.

\section{INSERT TABLE 1 HERE}

\subsection{Distribution by industry}

The published papers were also categorized into different industries. The category of 'General - Cross-industry' was the group with the greatest number of publications compared to other industries. Corresponding to Table 2 , the second most noticeable sector was the Textile, Garment and Footwear industries (12 per cent), followed by Tourism and Hospitality (10 per cent). These findings are not surprising because these industries, despite being dominant contributors to the country's high growing export-oriented economy, have been criticized for their heavy use of labour (Nayak, Akbari, \& Far, 2019), enormous plastic waste footprint (Hien TT Nguyen, Costanzo, \& Karatas-Özkan, 2020), and toxic chemicals discharged into the environment (T. T. H. Phan et al., 2020; Quan-Hoang Vuong et al., 2021). Therefore, firms operating in these sectors have faced market-driven pressures to implement green practices and adopt CSR-oriented standards to cope with progressive customer demand and trade barriers when trying to integrate into the international markets. Other industries that were researched by more than two papers included Healthcare ( 8 per cent), Food and Beverage ( 8 per cent), Banking (4 per cent), Software (4 per cent) and Logistics (3 per cent).

\section{INSERT TABLE 2 HERE}

\subsection{The nature of CSR knowledge}

Table 3 shows that empirical papers have significantly outnumbered theoretical articles in the sample, with only three articles being classified as non-normative theoretical research (Patterson \& Rowley, 2019; Phan Van \& Podruzsik, 2018; Tien \& Hung Anh, 2018). These results are consistent with the general pattern in CSR research in Asia, as noted by C. H. Kim and Moon (2015) and CSR research in developing countries in Amos (2018). The absence of conceptual papers with a dominant framework about CSR in Vietnam may also reflect the early stage of this stream of research. This is a common observation in the history of science, where a discipline is in its 
infancy with no influential mainstream sources to outline an implicit common awareness or knowledge (Akbari \& McClelland, 2020). Table 3 also reports that a large majority, 94 out of 140 papers (67 per cent), was quantitative with respect to the research design. In contrast, only 22 out of 140 papers (16 per cent) were qualitative in orientation, followed by relatively few papers that used a mixed-method ( 24 out of 140 papers). This is a surprising finding as it contrasts with the results of Amos (2018) that show an emphasis on qualitative approach among CSR research in developing countries.

\section{INSERT TABLE 3 HERE}

Figure 5 shows that despite a prevalence of qualitative articles at the early stage, the number of quantitative articles increased steadily between the two recent five-year intervals, 2011-2015 and 2016-2020. This indicates that studies related to CSR in Vietnam have focused on testing theories or frameworks with their origins firmly rooted in advanced economies rather than theory generation. To a certain extent, these trends suggest the absence of contextualisation efforts, in which researchers may fail to thoroughly investigate the peculiar institutional constellations and characteristics of the country and its influences on the adoption and transition of CSR as a Western concept in Vietnam. Given the context-specific relevance of CSR, it may be imperative that scholars pay more attention to explore interpretations (by using qualitative research) about how CSR is understood and the nature of CSR activities undertaken in Vietnam, as suggested by Jamali (2010).

\section{INSERT FIGURE 5 HERE}

\subsection{The focus of CSR research}

\section{Dominant CSR themes}

As an academic field, it is expected that CSR in Vietnam research will exhibit a number of different focuses reflecting different aspects of CSR. In this section, we classified the dominant themes of the articles by four areas, namely social, ethical, environmental, and labour-related, followed by a report on how this may have changed over time. The social category refers to a relatively long-standing focus for CSR research, approaching CSR from a wider and holistic perspective which encompasses simultaneously environmental, ethical, and social aspects. The other categories are based on dimension-focused evaluations of CSR. In particular, the ethical aspect of CSR is another well-established focus of research evidenced by a number of dedicated CSR studies looking at codes of conduct, moral standards, and ethical responsibility. The environmental theme has recently emerged as a distinct focus for scholars, valuing environmental responsibility in its own right. Similarly, the labour dimension refers to CSR studies to delineate an appropriate approach to, and normative reference for, employment relations 
that may encompass freedom of association, non-discrimination, occupational health, and safety and working conditions.

Given highly permeable boundaries, in cases when an article was identified for two or more CSR themes, it was assigned to the thematic category that appears to be the dominant discussion of the paper. To arrive at a decision, the methodology, results, and discussions sections had to be read carefully before deciding whether the article should be included in a particular thematic focus in the review. Any such classification will consist of some overlaps and lacuna. We contend, however, that this classification is aligned with other reviews (e.g., Lockett et al., 2006; Moon \& Shen, 2010; Taneja et al., 2011) and echoes practical management distinctions.

The percentage of articles by the four dominant themes is presented in Figure 6 . The data indicate that articles on the 'Social' theme dominate, accounting for 62 per cent of the articles. The remaining themes, 'Ethical', 'Labour-related', and 'Environmental', account for 15 per cent, 11 per cent, and 12 per cent respectively. The overwhelming dominance of the 'Social' theme is not surprising given our knowledge of the characteristics of CSR research in developing countries (Amos, 2018). Arguably, CSR remains the preferred term in describing the role of business towards community development. Also, social issues are given prominence over other issues, and there is a strong tendency for scholars to emphasise philanthropic practices in developing countries (Jamali \& Karam, 2016).

\section{INSERT FIGURE 6 HERE}

Figure 7 shows that the number of articles focused on the environmental theme and the labour-related theme increased significantly in the five-year intervals from 2016 to 2020 . Although seeking explanations for this pattern is beyond our objectives, one might suggest that it reflects the observation in recent years that the Vietnamese government has started to pay attention to environmental issues (Fadly, 2020; Ortmann, 2017) and employment relations to address the growth of labour disputes and strikes during the past decade (Anner, 2018; Phuong, 2017). In this regard, the relatively low prevalence of articles focused on ethics-related topics in the fiveyear intervals from 2016 to 2020 is particularly puzzling, given that Vietnam is characterized by opaque regulatory climates, weak institutions, rampant corruption, and widespread unethical business practices associated with a robust spirit of pragmatism (N. C. Pham, Shi, Fogel, Li, \& Pham, 2020; M. C. Vu, 2019).

\section{INSERT FIGURE 7 HERE}

\section{Research objectives}

We categorised the studies across seven types on the basis of the core research objective, namely Argumentative (e.g., presenting two sides of a controversial issue); Analytical (e.g., analysing different viewpoints); Definition 
(e.g., containing facts from other articles); Compare and Contrast (e.g., comparing different theoretical viewpoints); Cause and Effect (e.g., tracing expected results from a particular policy); Report (e.g., summarising the situation to date; identification of the main issue or concern; a breakdown of the elements of this main issue and recommendations on how to address the issue based on research on the topic), and Interpretive (e.g., supporting a hypothesis statement and findings). Table 4 shows that 77 per cent of the CSR in Vietnam research has focused on tracing cause and effect to test a theoretical framework. There has also been a greater emphasis on interpretive and analytical articles (10 per cent and 7 per cent respectively) than report and argumentative articles ( 1 per cent) and compare and contrast ( 3 per cent).

\section{INSERT TABLE 4 HERE}

\section{Review of theoretical perspectives}

Following the selected (143) articles, we grouped the papers into three categories: those that used a single theoretical perspective; those that combined two or more theories; and those that did not specify their theoretical framework. Tables 5 indicates that, over the studied period (2000-2020), CSR in Vietnam research has drawn predominantly on a single theoretical perspective ( 33 per cent) to support their findings and conclusions. However, it is mind-boggling that 37 per cent of papers did not specify their theoretical perspectives.

\section{INSERT TABLE 5 HERE}

Table 6 summarizes the dominant theories used in CSR in Vietnam research. In this table, we follow Frynas and Yamahaki (2016), in which conceptual frameworks or models directly associated with a CSR context, such as Carroll's pyramid and triple bottom line theory, were excluded. Stakeholder theory is the most prominent theoretical lens with 37 articles, which have focused mainly on explaining the impact of CSR on organizational performance (Kabir \& Thai, 2017; Xie, Jia, Meng, \& Li, 2017) and the stakeholders' impact on CSR-related activities (C. Kim, Kim, Marshall, \& Afzali, 2018). The dominance of stakeholder theory matches prior reviews by Pisani et al. (2017), Ho Lee (2017), and Frynas and Yamahaki (2016). Other dominant theories include agency theory (15 articles), signalling theory ( 9 papers), and institutional theory ( 8 papers). These theories have been considered a conventional group of theories of CSR research by Amos (2018). This suggests that scholars have applied 'conventional wisdom' when it comes to selecting theories to ground their research in CSR in Vietnam.

\section{INSERT TABLE 6 HERE}

As shown in Table 6, scholars have borrowed theories from different fields, such as sociology (social capital theory, structural holes theory, and social identity theory), economics (Gray et al.'s economic-based theories, agency theory and institutional theory) and psychology (Lewin's field theory, attachment theory, self- 
consistency theory, social exchange theory and theory of reasoned action), in researching CSR in Vietnam. These theories, with their explanatory power, have been useful in understanding the predicting, mediating, and moderating roles of CSR in the context of Vietnam. For example, the application of Lewin's (1951) field theory has been used to explain the moderating role of CSR in the effect of organizational ambidexterity on entrepreneurial orientation (Tuan, 2016b), and the predicting role that CSR played on the relationship between psychological contract and knowledge sharing among employees (Tuan, 2016c). On the other hand, Canh, Liem, Thu, and Khuong (2019) have used signalling theory to explain the effects of CSR (as a decent signalling channel) on the performance of Vietnamese manufacturing firms. Institutional theory, on the basis of its deep-seated tradition in social sciences, has been a useful theoretical lens for understanding the impacts of the institutional environment on the CSR behaviours of firms (Do \& Nguyen, 2020; H. T. T. Pham, Jung, \& Lee, 2020). Moreover, it also offers more critical and sociological interpretations by either comparing and contrasting in terms of crosscountry aspects (Cox \& Le, 2014; Xie et al., 2017) or studying the effectiveness of CSR strategies in the different institutional environments of home or host countries (Han, 2016; C. Kim et al., 2018).

\section{Methodological review}

Figure 8 shows that structured and semi-structured questionnaires (93 papers) have been the most dominant surveying instrument among CSR in Vietnam articles. Interviews and analysis of secondary database sources (as known as database research) are also popular research design methods, followed by case studies. Experimental research, focus group (including expert panel approach), and observations are less popular methodologies, while action research has not been employed in the dataset. These results are consistent with Egri and Ralston (2008).

\section{INSERT FIGURE 8 HERE}

\section{Sources and nature of data}

The surveyed articles have collected data either from primary or secondary data sources. Articles involving both sources have been categorised as mixed sources. Most articles in our sample rely on primary sources of information (Figure 9), representing a significantly distinct pattern from CSR research more widely (Taneja et al., 2011). This may suggest reduced availability of databases related to CSR in Vietnam, reflecting the inherently weak 'CSR institutional infrastructure' of developing countries, as suggested by Jamali and Neville (2011). The most commonly used secondary data sources are annual reports of companies, audit reports, factory inspection reports, the Vietnam Enterprise Survey, and the Vietnam Technology and Competitiveness Survey.

Data were also classified by time horizon as longitudinal or cross-sectional (Sekaran \& Bougie, 2009). Longitudinal studies gather data at two or more points in time, while cross-sectional studies collect data at one 
particular point in time. Figure 9 shows a predominance of cross-sectional studies that represent two-thirds of the total, once again in contrast to the findings of Taneja et al. (2011).

\section{INSERT FIGURE 9 HERE}

With respect to firm types, one of the areas that have received relatively less attention within the research agenda pertains to the role of small and medium enterprises (SMEs) in CSR in Vietnam. In particular, only five articles in our sample specifically investigated CSR in SMEs (Malesky \& Taussig, 2017; Nhat Minh \& BichNgoc Thi, 2020; Phan Van \& Podruzsik, 2018; Tran \& Jeppesen, 2016; Van \& Nguyen, 2019) and one article focused on CSR in the context of family firms (Hien TT Nguyen et al., 2020). According to Jamali, LundThomsen, and Jeppesen (2017), this may suggest a sceptical view among scholars that the engagement of Vietnamese SMEs with social and environmental standards is spontaneous and symbolic of masking and mitigating their noncompliance with fundamental principles and basic tenets of CSR.

Moreover, in Vietnam, the government governs the society with socialist doctrine. Despite the increasing diminution of state ownership, state-owned enterprises still retained favoured status in the country. These characteristics set out a novel context for CSR in Vietnam research, as evident in a number of recent papers investigating the role of CSR practices in public sector organisations (Huy \& Phuc, 2020; Limbu, Pham, \& Mann, 2019; Tuan, 2016a), the role of the government in the development of Vietnamese agricultural cooperatives - a socially-oriented business (Cox \& Le, 2014), and the impact of state/government ownership on CSR engagement of firms (D. Choi, Chung, Kim, Kim, \& Choi, 2020; Hoang, Abeysekera, \& Ma, 2019; Kabir \& Thai, 2017; Luong, Jorissen, \& Paeleman, 2019; A. H. Nguyen \& L. H. Nguyen, 2020; H. T. T. Pham et al., 2020; K. A. Vu \& Buranatrakul, 2018).

Data analysis

All empirical papers tested either a hypothesis or a research question, and most quantitative studies carried out validity and reliability tests. Exploratory factor analysis (EFA) and confirmatory factor analyses (CFAs) are the most popular statistical tests of convergent and discriminant validity. At the same time, Cronbach's alpha is used to test the reliability (internal consistency) for each factor. However, in some of the studies based on secondary data, those tests were not carried out (such as Malesky \& Taussig, 2017; L. T. Nguyen \& K. V. Nguyen, $2020 ;$ H. T. T. Pham et al., 2020). This may indicate that researchers assume that already published secondary data do not require further assessments of validity or reliability. Figure 10 shows that the most dominant quantitative research techniques are structural equation modelling (a combination of factor analysis and multiple regression) together with descriptive statistics, followed by regression analysis, correlation analysis and variance analysis. Partial least 


\section{Discussion}

\subsection{CSR as a research field}

Our comprehensive review of 143 articles on CSR in Vietnam, published from 2000 to 2020, identified four main features. First, CSR studies focused on Vietnam have a life cycle that is currently increasing or pre-maturity. This observation is not surprising as CSR adoption has a relatively short history in Vietnam. In 2012, there was a turning point in the growth of CSR in Vietnam research, most likely as an academic response to the increased integration of the country in the global economy. Growth in CSR research is therefore expected to grow in the forthcoming years in Vietnam. Second, CSR in Vietnam is heavily empirical and increasingly quantitative, with a scant proportion of normative and non-normative theoretical articles. This may suggest that researchers are testing Western-style theoretical frameworks by using empirical data from Vietnam. Our examination also indicates that most of the studies in our sample failed to propose a research design capturing the complexity of the Vietnamese context, which represents a reason for concern since CSR practice is strongly context-dependent, as suggested by Örtenblad (2016).

Third, CSR in Vietnam research has emphasised social issues over environmental responsibility. Our analysis also found that many studies are based on predominantly Western definitions of CSR. Therefore, a lack of research focus on the environmental aspect of CSR is not surprising because this aligns with Dahlsrud's (2008) finding that the environment received, by a significant amount, the lowest ratio of the five dimensions kernel to CSR definitions (namely environment, social, labour, and ethical voluntariness), and Carroll's (1999) finding that the environment was not featured in early definitions of CSR. However, given the recent emphasis on ecological sustainability by the Vietnamese government and business leaders, our analysis suggests that CSR in Vietnam research may gradually shift from general ethical concerns and emphasise harmonious human relationships to concerns about the environment.

Fourth, studies of CSR in Vietnam are not dominated by a particular theoretical approach. The lack of a clear dominant paradigm is illustrated by an imbalance between theoretical and empirical CSR knowledge. A 
large fraction of the studies is not theoretically informed. Even if they are, the purpose of using theories and models is rarely stated in detail. The absence of a dominant CSR paradigm suggests that CSR in Vietnam could best be described as in a continuing state of emergence, consistent with findings in the status of CSR in China in 2007 (Moon \& Shen, 2010). The recent increase in the number of theories and the adoption of mixed-theory research in recent years seems to indicate a gradual growth and sophistication of the field.

\subsection{CSR as a concept}

The arena of CSR in Vietnam, as we have made evident above, constitutes an emerging stream of literature consisting of divergent perspectives on the topical, theoretical, and methodological fronts. However, we argue that the most significant gap in CSR in Vietnam research is the absence of context-sensitive studies. Bridging this gap requires researchers to take into account the peculiar institutional constellations and characteristics of Vietnam. To provide a more solid foundation for future CSR research focused on Vietnam, we propose a model of CSR development in the Vietnamese context. This aims to reduce some of the complexity of context and enable scholars to identify potential gaps or unexplored connections between the context and the literature. The basis of the model consists of five stages, namely Ethics-driven CSR, Pragmatic CSR, Socialist-driven CSR, CSR Identity, and CSR Integration. These stages are discussed in depth below.

\section{Stage 1: Ethics-driven CSR}

Throughout its history, Vietnam has been influenced by 'tam giao' (literally "three teachings"), a blend of Confucianism, Taoism, and Buddhism, and this has fostered an ethics-driven CSR. For example, the core of Vietnamese Confucianism consists of five elements, namely 'Nhan' (humanity and benevolence), 'Nghia' (righteousness), Le (propriety); Tri (wisdom) and 'Tin' (honesty and faithfulness). Together they promote selfcultivation, benevolence towards others, symbiosis in human relationships and a desire to contribute to the community. In a similar sense, Buddhism's common principles of The Four Noble Truths, The Eightfold Path and The Law of Karma, and the notion of compassion for all living beings, has also established ethical standards to counter excessive selfishness and individualism, guiding Vietnamese people to righteousness, ethical conduct, and justice (Vu \& Tran, 2021). Taoism, through the concept of yin-yang, has also offered a worldview based on the natural approach to life, which involves reciprocity, moderation, and detachment as a path to the cultivation of virtues (Jamieson, 1993). Taoism differs from Confucianism in that it does not preach to people how they should live but instead follows the laws of nature and affirms the goodness of human nature to encourage humility, impartiality, and control over passions. Such long-lasting ethical foundations embedded in Vietnam's religion and 
philosophical beliefs uphold responsible business practices and, therefore, potentially influence the manifestations of CSR in Vietnam before its adoption from the West.

\section{Stage 2: Pragmatic CSR}

Throughout Vietnamese history, commerce was discouraged. During feudalism, merchants were placed on the lowest of four grades in the official Vietnamese social hierarchy due to the view that they did not produce any goods (Q. H. Vuong et al., 2018). Therefore, despite some periods of artisan entrepreneurship, economic life was mainly agrarian and village-oriented, and small-scale commerce was usually reserved for women and Chinese traders (Jamieson, 1993). In the mid-19th century, capitalism was introduced during the French colonization. However, under colonial rule, economic activity mostly served foreign rulers and a small class of wealthy Vietnamese. After the reunification in 1975 , the government implemented a centrally planned economy that banned private property rights and free-market activity (Edwards \& Phan, 2014). Hence, for a long period of Vietnamese history, rational business culture was absent.

Business thinking only started to take root in society in 1986 with the adoption of 'chinh sach mo cua' (an open door), a liberal and multi-sector pro-market policy (Q. H. Vuong, 2014). However, the main target for Vietnamese enterprises during this period was economic growth and profitability, which often resulted in pragmatic business decisions (Edwards \& Phan, 2008). The escalation of competitive dynamics and the weak regulatory regime also created enabling conditions for unethical business practices to flourish (Anner, 2012). The first Commercial Law was only officially enacted in 1997 and considered a fundamental landmark to prevent irresponsible acts that adversely affect the commercial environment (Edwards \& Phan, 2008). This suggests that in the period from 1986 to 1997 , it was likely that there was either an absence of a holistic perspective towards CSR in Vietnam or there was a pragmatic CSR conceptualisation towards economic responsibility, which emphasized economic profit as merely the social responsibility of business.

\section{Stage 3: Socialist-driven CSR}

Vietnam remains a one-party system led by the Communist Party of Vietnam (CPV) since 1954 in the North and since 1975 over the whole country (Gainsborough, 2010). In the period from 1975 to 1986, the government was responsible for assigning jobs and ensuring equal distribution of wealth and access to education, basic health care, food and clothing (Edwards \& Phan, 2014). Together with the provision of a socialist contract (i.e., job security and stable benefits), workers were also treated with respect, kindness, and flexibility (Tran \& Jeppesen, 2016). At the cultural level, the government encouraged solidarity, guild culture, philanthropic endeavours in order to promote social harmony and cohesion in a socialist-collectivist society (Jamieson, 1993). Although since 1986, 
the socialist safety net has shrunk with the advance of capitalist practices, the dominance of CPV is still present in contemporary society (Q. H. Vuong, 2014).

The CPV retains prerogative powers in a wide array of state-owned enterprises (SOEs) and joint-stock industrial companies, and its influence on business activities remains profound (Q. H. Vuong, 2014). This results in a situation where social duties (i.e., towards socialist aspirations) overlap with and sometimes prevail over business (i.e., maximising firm value). For example, a longitudinal study reported that state ownership enhances voluntary disclosure of employee-related CSR information (regarding workers care and welfare) among Vietnamese listed non-financial firms (K. A. Vu \& Buranatrakul, 2018). Another study also pointed out that Vietnamese firms have shown a tendency to follow government calls to contribute to community development projects (Kabir \& Thai, 2017). In tandem with these political pressures, the government also asserts its legislative dominance to govern business activities with socialist doctrine (T. Vu, 2010). For example, state legislation generally aims to protect the working class from discrimination and exploitation (Rodan, Hewison, \& Robison, 2001) through restrictions on regular working hours, strict conditions for dismissal, and an employer's health and safety obligations (Clarke, Lee, \& Chi, 2007). Moreover, the Labour code also protects marginalised groups in society, such as female employees who are granted additional rest breaks, shorter regular working hours, and a 6month paid maternity leave (K. D. Nguyen, Nguyen, Nguyen, \& Tran, 2021). Therefore, one may deduce that the development of CSR in Vietnam is representative of a new form of socialist ideology. The orientation of CSR practices among businesses in Vietnam towards social welfare and employees have been driven by the initiatives of the socialist government.

Stage 4: CSR Identity

The economic liberalization after the Law on Foreign Investment in 1987 brought Western CSR into the Vietnamese market. Since 2000, many Vietnamese enterprises in labour-intensive and trade-oriented industrial sectors have mimicked and accepted international standards relating to working conditions, rights, health and safety issues, and wage conditions due to pressures from foreign purchasers (S. Y. Lee, 2016; Newman, Rand, Tarp, \& Trifkovic, 2018). Consequently, new industry standards and practices based on respect for people, communities, and the environment have gradually developed. CSR issues have also penetrated the government agenda, with the Chamber of Commerce and Industry of Vietnam (VCCI) and the Ministry of Labour, War Invalids and Social Affairs also establishing CSR campaigns, particularly in the garment industry (Tran, 2011).

However, presently, the country still lacks a public CSR policy. Currently, TCVN ISO 26000:2013, which the Ministry of Science and Technology published in 2013, is the only official guideline for CSR practices 
in Vietnam. Moreover, the government displays weak enforcement and considerable deficiencies in addressing regulatory voids (Anner, 2018). For example, despite the maximum regular working hours of 48 hours per week, no tools are available to ensure employers are compliant, especially in small and medium-sized textile factories (Tran \& Jeppesen, 2016). In addition, legislation may not capture the changing expectations of society regarding the behaviour of companies (Blowfield \& Murray, 2014). Therefore, other efficient facilitators of CSR are needed in Vietnam.

\section{Stage 5: CSR Integration}

CSR only started to evolve in the country in 2010 (UNIDO, 2013). This is observed in the case of international and non-governmental organisations (NGOs) which promoted sustainable business practices (Tran, 2011; Trifkovic, Markussen, Newman, \& Rand, 2018) and a shift among Vietnamese enterprises to a more proactive approach to CSR assessment, auditing, and accreditation for access to the global market (Anner, 2018; Vo \& Arato, 2020). Additionally, a new Vietnamese working class with a greater awareness of their rights and global issues such as business ethics, gender equality, work-life balance, slavery, and climate change has emerged (Edwards \& Phan, 2014), creating a more favourable environment for CSR to evolve in Vietnam.

Growing ecological concerns globally have also led to a call for greater regulation of business practices in Vietnam (Newman et al., 2018; X.-H. Nguyen \& Trinh, 2020). In particular, Vietnam has reiterated its commitment to the UN's 2030 Agenda for Sustainable Development (Agenda 2030) and its 17 Sustainable Development Goals with 169 specific targets. Moreover, to foster further integration into the global economy, the Vietnamese government has been under pressure to participate in new-generation free trade agreements, which deal with the diverse aspects of CSR. For example, Vietnam has recently ratified the Comprehensive and Progressive Agreement for the Trans-Pacific Partnership. This free trade agreement promotes CSR and compliance with international standards on labour rights and environmental protection (Khan, 2018). Those driving factors are expected to facilitate the development of CSR in Vietnam.

However, explosive economic growth in Vietnam has brought along social problems and widespread scandals directly associated with multinational and local businesses (M. Nguyen et al., 2018). In this period, one of the barriers to CSR development is the government's control over civil society institutions through bureaucratic structures at central, provincial, district and local levels. For example, independent unionism is illegal in Vietnam (Clarke et al., 2007), while NGOs do not enjoy the same independence from the state that is observed in the West. Another civil society institution that can have an impact on CSR development is the media. Still, in Vietnam, the state also retains tight control over the press through state-run media (Gainsborough, 2010). Media ethics in 
Vietnam is another obstacle to the development of CSR. The press has been criticized as an agent of business and for receiving bribes (TN News, 2011). Therefore, media ethics violations may contribute to increased public scepticism over CSR as a PR strategy or crisis communication strategy to minimize a tarnished reputation (Bilowol \& Doan, 2015).

\section{Conclusions, implications, and future studies}

\subsection{Future Research Agenda}

This part sets out promising trajectories for new CSR in Vietnam research that will help to extend the field. First, CSR in Vietnam research should shift from description to theorization explicitly tied to the context of Vietnam. This is exemplified by Nguyen et al. (2018), which proposed a conceptual framework for CSR in Vietnam. The 'how' and 'should' aspects are important starting points for CSR in Vietnam research to keep pace with changing practices and societal expectations. Second, further research should pay closer attention to the complexity of context to reflect its embeddedness and multi-level nature. For example, the frameworks of Athanasopoulou and Selsky (2015) and Matten and Moon (2008) can open up CSR in Vietnam research field to new research designs. This direction is illustrated by Wrana and Diez (2018), who applied a multi-level analysis to investigate the relationship between the adoption of CSR standards and business performance (firm-level), the varying impacts of spatial proximity to MNEs (district level), and the importance of regional institutions (province-level) on the implementation of global CSR certificates among private domestic firms in Vietnam.

Another important concern is the need for methodological diversification. Although empirical studies that employ surveys have dominated CSR research focused on Vietnam, the direct application of measures derived from other countries may yield invalid results. Therefore, more qualitative research would be more appropriate, especially since the CSR phenomenon is still not well defined in Vietnam. As one of the pioneering contributions, Tran and Jeppesen (2016) employed in-depth semi-structured interviews and document analysis and was the first to bring in the voices of managers and local workers in small and medium-sized enterprises in Vietnam as a way of explaining some of the core propositions of institutional theory in the context of formal and informal CSR practices in the Vietnamese textiles, garment, and footwear manufacturing sectors.

In addition, our analysis has illustrated the absence of action research, causing concerns over the current purpose of CSR in Vietnam. As Athanasopoulou and Selsky (2016) suggested, CSR researchers have a duty not only to study how CSR practices take place in a local context but also to identify pitfalls and recommend modest or radical changes in CSR practices. Thus, we encourage researchers to work actively with practitioners on dayto-day CSR issues to improve CSR practices in Vietnam. 
Finally, our review shows that topics related to environmental CSR seem to be the area that is addressed least often. The lack of research pertaining to environmental issues suggests that CSR in Vietnam research may not keep up with the new global forces and trends. However, there is an increasing public awareness and mobilization around environmental aspects of CSR due to the severe air pollution and active engagement in social media, which may provide new momentum for CSR development in Vietnam.

\subsection{Practical implications}

In light of our analysis, CSR in Vietnam is an emerging item for civil society, the Vietnamese State and Party, and Vietnamese businesses, at the firm and sector levels, at home and abroad. Therefore, our conclusions also have practical implications. Firstly, it may help managers gain a deeper understanding of the political, economic, institutional, and societal dynamics that may shape the growth of CSR in Vietnam. Moreover, this study raises the central question of the role of civil society organizations by offering wider insights into the peculiarities of the Vietnamese context. In the early development of CSR in Vietnam, civil society actors were less influential in Vietnam than in the West. Therefore, the categorization of research on CSR in Vietnam may help practitioners design strategies that can expand the space for civil society activism. This study also serves as a call for Vietnamese authorities to address societal issues such as pollution and labour exploitation by advancing CSR. The party-state system, strongly influenced by the Communist Party, has been the dominant feature in the Vietnamese business system. On the one hand, this authoritarian background challenges core theoretical assumptions of CSR, namely being voluntary and driven by business. On the other hand, policymakers could see this as an opportunity to mediate societal demands to business and to deploy CSR for governance purposes, to maintain the regime's legitimacy while also sustaining economic growth.

\subsection{Limitations}

Due to limited resources, the scope of the study is confined to three databases. These databases predominantly consist of peer-reviewed English language articles which provide comparative insights on the evolution of CSR research in Vietnam. We did not intend to ignore Vietnamese language literature in our research but at the time of writing there were no Vietnamese language publications indexed in these databases. The absence of Vietnamese language literature suggests that future studies need to employ different selection criteria and methodology to include Vietnamese language sources. Therefore, we must be cautious in making the assumption that CSR research fully reflects CSR practices in Vietnam since there are lag effects between practices and research, suggesting that some of our conclusions may underestimate recent developments in the field. 


\subsection{Concluding remarks}

This study aims to provide a better understanding of the peculiarities of the Vietnamese context through a comprehensive review of the literature on the emerging field of CSR in Vietnam. Despite the growth of research on CSR in Vietnam, this study highlighted a number of gaps. Therefore, this study suggests areas for improvement of future research, such as a call for more scholarly attention to details about the Vietnamese institutional context and more context-sensitive and multilevel CSR research. 


\section{References}

Akbari, M., \& McClelland, R. (2020). Corporate social responsibility and corporate citizenship in sustainable supply chain: A structured literature review. Benchmarking: An International Journal, 27(6), 1799-1841. 10.1108/BIJ-11-2019-0509

Amos, G. J. (2018). Researching corporate social responsibility in developing-countries context: A systematic review of the literature. International Journal of Law and Management, 60(2), 284-310. 10.1108/IJLMA-04-2017-0093

Anner, M. (2012). Corporate social responsibility and freedom of association rights: The precarious quest for legitimacy and control in global supply chains. Politics and Society, 40(4), 609-644. $10.1177 / 0032329212460983$

Anner, M. (2018). CSR participation committees, wildcat strikes and the sourcing squeeze in global supply chains. British Journal of Industrial Relations, 56(1), 75-98. 10.1111/bjir.12275

Athanasopoulou, A., \& Selsky, J. W. (2015). The social context of corporate social responsibility: Enriching research with multiple perspectives and multiple levels. Business \& Society, 54(3), 322-364. $10.1177 / 0007650312449260$

Athanasopoulou, A., \& Selsky, J. W. (2016). The social context in CSR research: A contextualist approach with critical applications. In A. Örtenblad (Ed.), Research Handbook on Corporate Social Responsibility in Context (pp. 46-64). Northampton, MA: Edward Elgar Publishing. 10.4337/9781783474806.00012

Bass, A. E., \& Milosevic, I. (2016). The ethnographic method in CSR research: The role and importance of methodological fit. Business \& Society, 57(1), 174-215. 10.1177/0007650316648666

Bilowol, J., \& Doan, M. A. (2015). Multinational corporations' role in developing Vietnam's public relations industry through corporate social responsibility. Public Relations Review, 41(5), 825-832. 10.1016/j.pubrev.2015.06.004

Blowfield, M., \& Frynas, J. G. (2005). Setting new agendas: Critical perspectives on corporate social responsibility in the developing world. International Affairs, 81(3), 499-513.

Blowfield, M., \& Murray, M. A. (2014). Corporate responsibility. Oxford, UK: Oxford University Press.

Campbell, J. L. (2007). Why would corporations behave in socially responsible ways? An institutional theory of corporate social responsibility. The Academy of Management Review, 32(3), 946-967. 10.2307/20159343 
Canh, N. T., Liem, N. T., Thu, P. A., \& Khuong, N. V. (2019). The impact of innovation on the firm performance and corporate social responsibility of Vietnamese manufacturing firms. Sustainability, 11(13), 3666. $10.3390 /$ su11133666

Carroll, A. B. (1999). Corporate social responsibility: Evolution of a definitional construct. Business \& Society, 38(3), 268-295. 10.1177/000765039903800303

Chen, W., \& Hirschheim, R. (2004). A paradigmatic and methodological examination of information systems research from 1991 to 2001. Information Systems Journal, 14(3), 197-235. 10.1111/j.13652575.2004.00173.x

Choi, D., Chung, C. Y., Kim, Y.-E., Kim, Y. J., \& Choi, P. M. S. (2020). Sustainable corporate ownership structures and earnings management in the Vietnamese stock market. Sustainability, 12(15), 6089. $10.3390 /$ su12156089

Choi, S. B., Feng, Y., Liu, J., \& Zhu, Q. (2019). Motivating corporate social responsibility practices under customer pressure among small-and medium-sized suppliers in China: The role of dynamic capabilities. Corporate Social Responsibility and Environmental Management, 26(1), 213-226. 10.1002/csr.1673

Clarke, S., Lee, C.-H., \& Chi, D. Q. (2007). From rights to interests: The challenge of industrial relations in Vietnam. Journal of Industrial Relations, 49(4), 545-568. 10.1177/0022185607080321

Conte, F., Vollero, A., Covucci, C., \& Siano, A. (2020). Corporate social responsibility penetration, explicitness, and symbolic communication practices in Asia: A national business system exploration of leading firms in sustainability. Corporate Social Responsibility and Environmental Management, 27(3), 1425-1435. 10.1002/csr.1895

Cox, A., \& Le, V. (2014). Governmental influences on the evolution of agricultural cooperatives in Vietnam: An institutional perspective with case studies. Asia Pacific Business Review, 20(3), 401-418. $10.1080 / 13602381.2014 .931045$

Crane, A., \& Matten, D. (2021). Covid-19 and the future of CSR research. Journal of Management Studies, 58(1), 280-284. 10.1111/joms.12642

Dahlsrud, A. (2008). How corporate social responsibility is defined: An analysis of 37 definitions. Corporate Social Responsibility and Environmental Management, 15(1), 1-13. 10.1002/csr.132

Davidson, D. K. (2016). The importance of context in understanding CSR. In A. Örtenblad (Ed.), Research handbook on corporate social responsibility in context. Cheltenham, UK: Edward Elgar Publishing. $10.4337 / 9781783474806.00011$ 
Denyer, D., \& Tranfield, D. (2009). Producing a systematic review. in Buchanan, D. and Bryman, A. (Eds), The Sage Handbook of Organizational Research Methods (pp. 671-689). London: Sage Publications.

Do, B., \& Nguyen, N. (2020). The links between proactive environmental strategy, competitive advantages and firm performance: An empirical study in Vietnam. Sustainability, 12(12), 4962. 10.3390/su12124962

Dzever, S., \& Gupta, B. (2012). Business process outsourcing industry in India: Additional benefits of a CSR approach. Asian Business \& Management, 11(3), 273-289. 10.1057/abm.2012.11

Edwards, V., \& Phan, A. (2008). Vietnam. In J. Benson \& Y. Zhu (Eds.), Trade unions in Asia: An economic and sociological analysis. London, UK: Routledge.

Edwards, V., \& Phan, A. (2014). Managers and management in Vietnam: 25 years of economic renovation (Doi moi). Oxford, UK: Routledge.

Egri, C. P., \& Ralston, D. A. (2008). Corporate responsibility: A review of international management research from 1998 to 2007. Journal of International Management, 14(4), 319-339. 10.1016/j.intman.2007.09.003

Fadly, D. (2020). Greening industry in Vietnam: Environmental management standards and resource efficiency in SMEs. Sustainability, 12(18), 7455. 10.3390/su12187455

Ferraro, F., Etzion, D., \& Gehman, J. (2015). Tackling grand challenges pragmatically: Robust action revisited. Organization Studies, 36(3), 363-390. 10.1177/0170840614563742

Frynas, J. G., \& Yamahaki, C. (2016). Corporate social responsibility: Review and roadmap of theoretical perspectives. Business Ethics: A European Review, 25(3), 258-285. 10.1111/beer.12115

Gainsborough, M. (2010). Vietnam: Rethinking the state. New York, NY: Palgrave Macmillan.

Han, C. M. (2016). Can CSR by MNEs enhance home country image? An empirical investigation with Asian MNEs in Vietnam. International Journal of Business Governance and Ethics, 11(3), 183-199. 10.1504/IJBGE.2016.081630

Ho Lee, T. (2017). The status of corporate social responsibility research in public relations: A content analysis of published articles in eleven scholarly journals from 1980 to 2015. Public Relations Review, 43(1), 211218. 10.1016/j.pubrev.2016.10.001

Hoang, T. C., Abeysekera, I., \& Ma, S. (2019). Earnings quality and corporate social disclosure: The moderating role of state and foreign ownership in Vietnamese listed firms. Emerging Markets Finance and Trade, 55(2), 272-288. 10.1080/1540496x.2018.1521801 
Hong, G., \& Kim, E. (2017). Overcoming country-of-origin image constraints on hiring: the moderating role of CSR. Asian Business \& Management, 16(4), 253-271. 10.1057/s41291-017-0023-5

Huang, Y.-F., Do, M.-H., \& Kumar, V. (2019). Consumers' perception on corporate social responsibility: Evidence from Vietnam. Corporate Social Responsibility and Environmental Management, 26(6) 10.1002/csr.1746

Huy, P. Q., \& Phuc, V. K. (2020). Does strategic corporate social responsibility drive better organizational performance through integration with a public sector scorecard? Empirical evidence in a developing country. Processes, 8(5), 596. 10.3390/pr8050596

Jamali, D. (2010). The CSR of MNC subsidiaries in developing countries: Global, local, substantive or diluted? Journal of Business Ethics, 93(2), 181-200. 10.1007/s10551-010-0560-8

Jamali, D., \& Karam, C. (2016). Corporate social responsibility in developing countries as an emerging field of study. International Journal of Management Reviews, 20(1), 32-61. 10.1111/ijmr.12112

Jamali, D., Karam, C., Yin, J., \& Soundararajan, V. (2017). CSR logics in developing countries: Translation, adaptation and stalled development. Journal of World Business, 52(3), 343-359. 10.1016/j.jwb.2017.02.001

Jamali, D., Lund-Thomsen, P., \& Jeppesen, S. (2017). SMEs and CSR in developing countries. Business \& Society, 56(1), 11-22. 10.1177/0007650315571258

Jamali, D., \& Neville, B. (2011). Convergence versus divergence of CSR in developing countries: An embedded multi-layered institutional lens. Journal of Business Ethics, 102(4), 599-621. 10.1007/s10551-011-08300

Jamieson, N. L. (1993). Understanding Vietnam. Berkeley, CA: University of California Press.

Kabir, R., \& Thai, H. M. (2017). Does corporate governance shape the relationship between corporate social responsibility and financial performance? Pacific Accounting Review, 29(2), 227-258. 10.1108/par-102016-0091

Karimova, G. Z., \& Goby, V. P. (2021). “Simple rules” as an approach to corporate selection of CSR strategies. International Journal of Organizational Analysis. 10.1108/IJOA-07-2020-2320

Khan, M. \& Sulaiman, R.B. (2021). On the linkage between CEOs' statements and CSR reporting: an analysis of visuals and verbal texts. Corporate Governance, 21(3), 515-535. https://doi.org/10.1108/CG-06-20200240 
Khan, M., Lockhart, J. C., \& Bathurst, R. J. (2018). Institutional impacts on corporate social responsibility: A comparative analysis of New Zealand and Pakistan. International Journal of Corporate Social Responsibility, 3(1), 1-13.

Khan, M., Lockhart, J., \& Bathurst, R. (2020). A multi-level institutional perspective of corporate social responsibility reporting: A mixed-method study. Journal of Cleaner Production 265 https://doi.org/10.1016/j.jclepro.2020.121739

Khan, M., Lockhart, J., \& Bathurst, R. (2021). The institutional analysis of CSR: Learnings from an emerging country. Emerging Markets Review, 46, 100752. 10.1016/j.ememar.2020.100752

Khan, M., Sulaiman, R., Nazir, O., \& Ahmad, W. (2020). Small size, bigger impact: Do SMEs care about social responsibility in Pakistan? In Mitra N., Schmidpeter R. (eds) Corporate social responsibility in rising economies. CSR, sustainability, ethics \& governance. Springer, Cham. https://doi.org/10.1007/978-3030-53775-3_5

Khanh, V. (2018, November 12). Vietnam becomes seventh country to ratify Trans-Pacific trade pact. Reuters. Retrieved from https://www.reuters.com/article/us-trade-tpp/vietnam-becomes-seventh-country-toratify-trans-pacific-trade-pact-idUSKCN1NH0VF

Kim, C., Kim, J., Marshall, R., \& Afzali, H. (2018). Stakeholder influence, institutional duality, and CSR involvement of MNC subsidiaries. Journal of Business Research, 91, 40-47. 10.1016/j.jbusres.2018.05.044

Kim, C. H., Amaeshi, K., Harris, S., \& Suh, C.-J. (2013). CSR and the national institutional context: The case of South Korea. Journal of Business Research, 66(12), 2581-2591. 10.1016/j.jbusres.2012.05.015

Kim, C. H., \& Moon, J. (2015). Dynamics of corporate social responsibility in Asia: Knowledge and norms. Asian Business \& Management, 14(5), 349-382. 10.1057/abm.2015.15

Lee, S. Y. (2016). Responsible supply chain management in the Asian context: The effects on relationship commitment and supplier performance. Asia Pacific Business Review, 22(2), 325-342. $10.1080 / 13602381.2015 .1070012$

Lee, T. H. (2017). The status of corporate social responsibility research in public relations: A content analysis of published articles in eleven scholarly journals from 1980 to 2015. Public Relations Review, 43(1), 211218. 10.1016/j.pubrev.2016.10.001 
Limbu, Y. B., Pham, L., \& Mann, M. (2019). Corporate social responsibility and hospital brand advocacy: Mediating role of trust and patient-hospital identification and moderating role of hospital type. International Journal of Pharmaceutical and Healthcare Marketing, 14(1), 159-174. 10.1108/IJPHM04-2019-0029

Lockett, A., Moon, J., \& Visser, W. (2006). Corporate social responsibility in management research: Focus, nature, salience and sources of influence. Journal of Management Studies, 43(1), 115-136. 10.1111/j.1467-6486.2006.00585.x

Lortie, J., \& Cox, K. C. (2018). On the boundaries of social entrepreneurship: A review of relationships with related research domains. International Entrepreneurship and Management Journal, 14(3), 639-648. 10.1007/s11365-018-0514-7

Luong, T. C. T., Jorissen, A., \& Paeleman, I. (2019). Performance measurement for sustainability: Does firm ownership matter. Sustainability, 11(16), 4436. 10.3390/su11164436

Malesky, E., \& Taussig, M. (2017). The danger of not listening to firms: Government responsiveness and the goal of regulatory compliance. Academy of Management Journal, 60(5), 1741-1770. 10.5465/amj.2015.0722

Matten, D., \& Moon, J. (2008). "Implicit" and "explicit" CSR: A conceptual framework for a comparative understanding of corporate social responsibility. The Academy of Management Review, 33(2), 404-424. 10.2307/20159405.

Mazboudi, M., Sidani, Y. M., \& Al Ariss, A. (2020). Harmonization of firm CSR policies across national contexts: Evidence from Brazil \& Sweden. International Business Review, 29(5), 101711. 10.1016/j.ibusrev.2020.101711

Moon, J., \& Shen, X. (2010). CSR in China research: Salience, focus and nature. Journal of Business Ethics, 94(4), 613-629. 10.1007/s10551-009-0341-4

Murphy, M. J., \& Smolarski, J. M. (2020). Religion and CSR: An Islamic "Political" model of corporate governance. Business \& Society, 59(5), 823-854. 10.1177/0007650317749222

Nayak, R., Akbari, M., \& Far, S. M. (2019). Recent sustainable trends in Vietnam's fashion supply chain. Journal of Cleaner Production, 225, 291-303. 10.1016/j.jclepro.2019.03.239

Newman, C., Rand, J., Tarp, F., \& Trifkovic, N. (2018). The transmission of socially responsible behaviour through international trade. European Economic Review, 101, 250-267. 10.1016/j.euroecorev.2017.10.013 
Nguyen, A. H., \& nguyen, L. H. (2020). Determinants of sustainability disclosure: Empirical evidence from Vietnam. The Journal of Asian Finance, Economics, and Business, 7(6), 73-84. 10.13106/jafeb.2020.vol7.no6.073

Nguyen, H. T., Costanzo, L. A., \& Karatas-Özkan, M. (2020). Stakeholders' perceptions of sustainable entrepreneurship within the context of a developing economy. Journal of Small Business Management, 1-40. $10.1080 / 00472778.2020 .1796465$

Nguyen, H. T., Hoang, T. G., \& Luu, H. (2019). Corporate social responsibility in Vietnam: opportunities and innovation experienced by multinational corporation subsidiaries. Social Responsibility Journal, 16(6), 771-792. 10.1108/SRJ-02-2019-0082

Nguyen, K.-D., Nguyen, D.-T., Nguyen, D.-D., \& Tran, V.-A. T. (2021). Labour law reform and labour market outcomes in Vietnam. Asia and the Pacific Policy Studies, 1-28. 10.1002/app5.328

Nguyen, L. T., \& Nguyen, K. V. (2020). The impact of corporate social responsibility on the risk of commercial banks with different levels of financial constraint. Asia-Pacific Journal of Business Administration, 13(1), 98-116. 10.1108/APJBA-12-2019-0252

Nguyen, M., Bensemann, J., \& Kelly, S. (2018). Corporate social responsibility (CSR) in Vietnam: A conceptual framework. International Journal of Corporate Social Responsibility, 3(9), 1-12. 10.1186/s40991-018$0032-5$

Nguyen, X.-H., \& Trinh, H.-T. (2020). Corporate social responsibility and the non-linear effect on audit opinion for energy firms in Vietnam. Cogent Business \& Management, 7(1), 1757841. $10.1080 / 23311975.2020 .1757841$

Nhat Minh, T., \& Bich-Ngoc Thi, P. (2020). The influence of CEO characteristics on corporate environmental performance of SMEs: Evidence from Vietnamese SMEs. Management Science Letters, 10(8), 16711682. 10.5267/j.msl.2020.1.013

Orlikowski, W. J., \& Baroudi, J. J. (1991). Studying information technology in organizations: Research approaches and assumptions. Information Systems Research, 2(1), 1-28.

Örtenblad, A. (2016). Research handbook on corporate social responsibility in context. Northampton, MA: Edward Elgar Publishing.

Ortmann, S. (2017). The Vietnamese government and institutional reforms. In S. Ortmann (Ed.), Environmental Governance in Vietnam: Institutional Reforms and Failures (pp. 67-98). Cham: Springer International Publishing. 10.1007/978-3-319-49760-0_3 
Patterson, L., \& Rowley, C. (2019). Ethical management and leadership: A conceptual paper and Korean example. Asian Journal of Business Ethics, 8(1), 1-24. 10.1007/s13520-019-00086-3

Pham, H. T. T., Jung, S.-C., \& Lee, S.-Y. (2020). Governmental ownership of voluntary sustainability information disclosure in an emerging economy: Evidence from Vietnam. Sustainability, 12(16), 6686. $10.3390 /$ su12166686

Pham, N. C., Shi, J., Fogel, J., Li, Y., \& Pham, H. H. (2020). Motivations for bribery and bribery in business: Vietnam past and present. Asia Pacific Business Review, 1-31. 10.1080/13602381.2020.1820721

Phan, T. T. H., Tran, H. X., Le, T. T., Nguyen, N., Pervan, S., \& Tran, M. D. (2020). The relationship between sustainable development practices and financial performance: A case study of textile firms in Vietnam. Sustainability, 12(15), 5930. 10.3390/su12155930

Phan Van, T., \& Podruzsik, S. (2018). CSR in developing countries: Case study in Vietnam. Management (18544223), 13(4), 287-300. 10.26493/1854-4231.13.287-300

Phuong, N. T. (2017). Workers' strikes in Vietnam from a regulatory perspective. Asian Studies Review, 41(2), 263-280. 10.1080/10357823.2017.1298568

Pisani, N., Kourula, A., Kolk, A., \& Meijer, R. (2017). How global is international CSR research? Insights and recommendations from a systematic review. Journal of World Business, 52(5), 591-614. 10.1016/j.jwb.2017.05.003

Rauf, F., Voinea, C. L., Bin Azam Hashmi, H., \& Fratostiteanu, C. (2020). Moderating effect of political embeddedness on the relationship between resources base and quality of CSR disclosure in China. Sustainability, 12(8), 3323. 10.3390/su12083323

Rodan, G., Hewison, K., \& Robison, R. (Eds.). (2001). The political economy of South-East Asia: Conflicts, crises, and change (2nd ed.). New York, NY: Oxford University Press.

Schneider, A. (2020). Bound to fail? Exploring the systemic pathologies of CSR and their implications for CSR research. Business \& Society, 59(7), 1303-1338. 10.1177/0007650319856616

Sekaran, U., \& Bougie, R. (2009). Research methods for business: A skill building approach (5th ed.). Chichester, West Sussex, UK: John Wiley \& Sons Ltd.

Seuring, S., \& Müller, M. (2008). From a literature review to a conceptual framework for sustainable supply chain management. Journal of Cleaner Production, 16(15), 1699-1710. 10.1016/j.jclepro.2008.04.020 
Taneja, S. S., Taneja, P. K., \& Gupta, R. K. (2011). Researches in corporate social responsibility: A review of shifting focus, paradigms, and methodologies. Journal of Business Ethics, 101(3), 343-364. $10.1007 / \mathrm{s} 10551-010-0732-6$

Tien, N. H., \& Hung Anh, D. B. (2018). Gaining competitive advantage from CSR policy change - Case of foreign corporations in Vietnam. Polish Journal of Management Studies, 18(1), 403-417. 10.17512/pjms.2018.18.1.30

Tilt, C. A. (2016). Corporate social responsibility research: The importance of context. International Journal of Corporate Social Responsibility, 1(1), 1-9. 10.1186/s40991-016-0003-7

TN News. (2011). Ex-journalist faces 15 years in jail for extortion. Thanh Nien News. Retrieved from http://www.thanhniennews.com/society/exjournalist-faces-15-years-in-jail-for-extortion-11605.html

Tran, A. N. (2011). Corporate social responsibility in socialist Vietnam: Implementation, challenges, and local solutions. In A. Chan (Ed.), Labour in Vietnam (pp. 119-159). Singapore: Institute of Southeast Asian Studies.

Tran, A. N., \& Jeppesen, S. (2016). SMEs in their own right: The views of managers and workers in Vietnamese textiles, garment, and footwear companies. Journal of Business Ethics, 137(3), 589-608. $10.1007 / \mathrm{s} 10551-015-2572-\mathrm{X}$

Trifkovic, N., Markussen, T., Newman, C., \& Rand, J. (2018). Corporate social responsibility in Vietnam. In S. Hsu (Ed.), Routledge Handbook of Sustainable Development in Asia (pp. 427-448). Boca Raton, FL: Routledge. 10.4324/9781351008204

Tuan, L. T. (2016a). How servant leadership nurtures knowledge sharing: The mediating role of public service motivation. International Journal of Public Sector Management, 29(1), 91-108. 10.1108/IJPSM-062015-0112

Tuan, L. T. (2016b). Organizational ambidexterity, entrepreneurial orientation, and i-deals: The moderating role of CSR. Journal of Business Ethics, 135(1), 145-159. 10.1007/s10551-014-2476-1

Tuan, L. T. (2016c). Psychological contract and knowledge sharing: CSR as an antecedent and entrepreneurial orientation as a moderator. Corporate Communications, 21(1), 2-19. 10.1108/CCIJ-09-2014-0058

Van, L. T.-H., \& Nguyen, P. A. (2019). Corporate social responsibility and SMEs in Vietnam: A study in the textile and garment industry. Journal of Risk and Financial Management, 12(4), 174. $10.3390 /$ jrfm 12040174 
Velte, P. (2021). Determinants and consequences of corporate social responsibility assurance: A systematic review of archival research. Society and Business Review, 16(1), 1-25. 10.1108/SBR-05-2020-0077

Vo, H. T. M., \& Arato, M. (2020). Corporate social responsibility in a developing country context: A multidimensional analysis of modern food retail sector in Vietnam. Agroecology and Sustainable Food Systems, 44(3), 284-309. 10.1080/21683565.2019.1607797

Vu, K. A., \& Buranatrakul, T. (2018). Corporate social responsibility disclosure in Vietnam: A longitudinal study. DLSU Business \& Economics Review, 27(2), 147-165.

Vu, M. C. (2019). Tensions and struggles in tackling bribery at the firm level: Perspectives from Buddhist-enacted organizational leaders. Journal of Business Ethics, 168, 517-537, 10.1007/s10551-019-04235-3

Vu, M. C., \& Tran, T. (2021). Trust issues and engaged Buddhism: The triggers for skillful managerial approaches. Journal of Business Ethics, 169(1), 77-102. 10.1007/s10551-019-04273-x

Vuong, Q. H. (2014). Vietnam's political economy in transition (1986-2016). Stratfor Wordview. Retrieved from https://worldview.stratfor.com/the-hub/vietnams-political-economy-transition-1986-2016

Vuong, Q. H., Ho, T., La, V.-P., Nhue, D., Bui, Q.-K., Cuong, N. P. K., . . Napier, N. K. (2018). 'Cultural additivity' and how the values and norms of Confucianism, Buddhism, and Taoism co-exist, interact, and influence Vietnamese society: A Bayesian analysis of long-standing folktales, using $R$ and Stan. Hanoi: Western University Hanoi (Centre for Interdisciplinary Social Research). 10.2139/ssrn.3134541

Vuong, Q. H., La, V. P., Nguyen, H. K. T., Ho, M. T., Vuong, T. T., \& Ho, M. T. (2021). Identifying the moralpractical gaps in corporate social responsibility missions of Vietnamese firms: An event-based analysis of sustainability feasibility. Corporate Social Responsibility and Environmental Management, 28(1), 3041. $10.1002 /$ csr.2029

Wang, L., \& Juslin, H. (2009). The impact of Chinese culture on corporate social responsibility: The harmony approach. Journal of Business Ethics, 88(3), 433-451. 10.1007/s10551-009-0306-7

Winter, M., \& Knemeyer, A. M. (2013). Exploring the integration of sustainability and supply chain management: Current state and opportunities for future inquiry. International Journal of Physical Distribution \& Logistics Management, 43(1), 18-38. 10.1108/09600031311293237

Wrana, J., \& Diez, J. R. (2018). Multinational enterprises or the quality of regional institutions - What drives the diffusion of global CSR certificates in a transition economy? Evidence from Vietnam. Journal of Cleaner Production, 186, 168-179. https://doi.org/10.1016/j.jclepro.2018.03.113 
Xie, X., Jia, Y., Meng, X., \& Li, C. (2017). Corporate social responsibility, customer satisfaction, and financial performance: The moderating effect of the institutional environment in two transition economies. Journal of Cleaner Production, 150, 26-39. 10.1016/j.jclepro.2017.02.192

Yu, A., Ding, H.-B., \& Chung, H.-M. (2015). Corporate social responsibility performance in family and nonfamily firms: The perspective of socio-emotional wealth. Asian Business \& Management, 14(5), 383412. $10.1057 / \mathrm{abm} .2015 .16$

Zanfardini, M., Aguirre, P., \& Tamagni, L. (2016). The evolution of CSR's research in tourism context: A review from 1992 to 2012. Anatolia, 27(1), 38-46. 10.1080/13032917.2015.1083207 
Figures and Tables
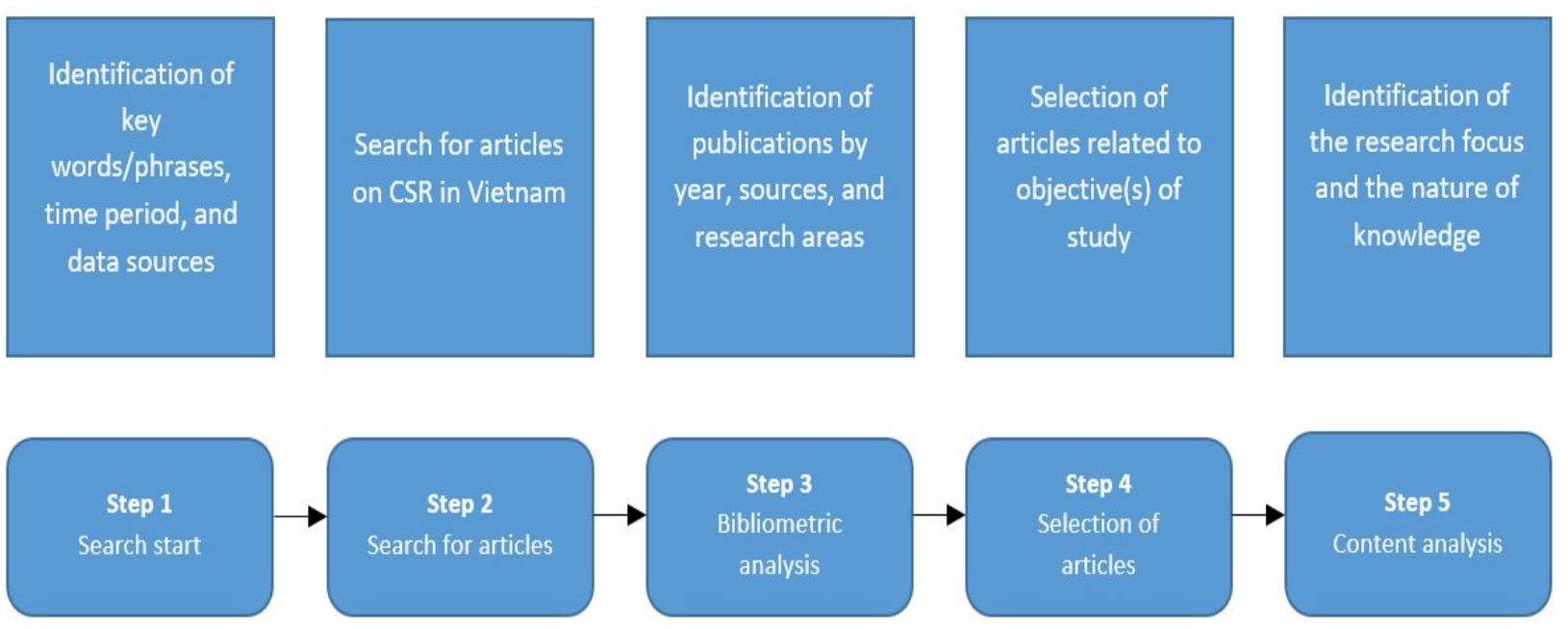

Step 5

Content analysis

Figure 1. Systematic literature review process
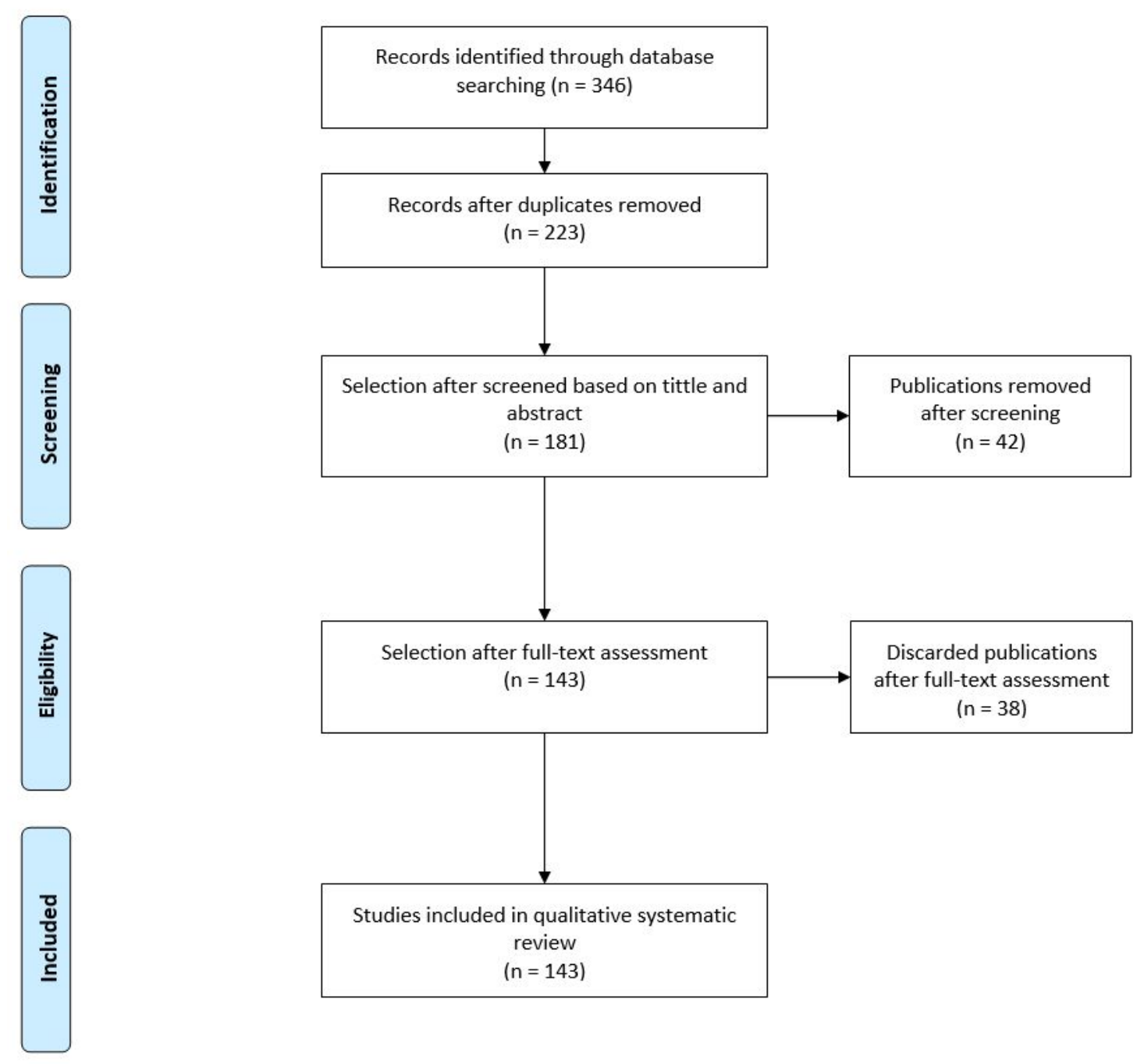

Figure 2. PRISMA flow diagram 

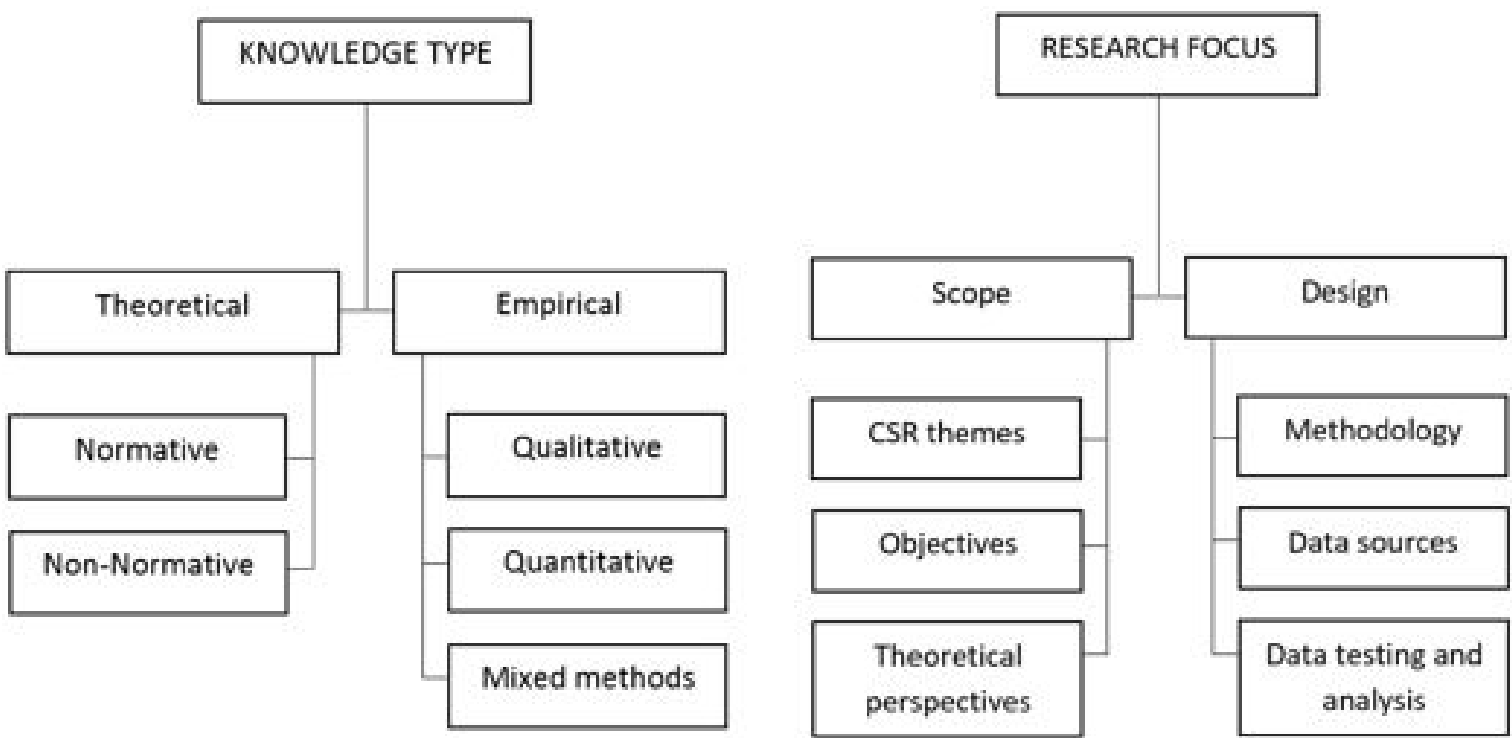

Figure 3: Classification of literature on CSR in Vietnam

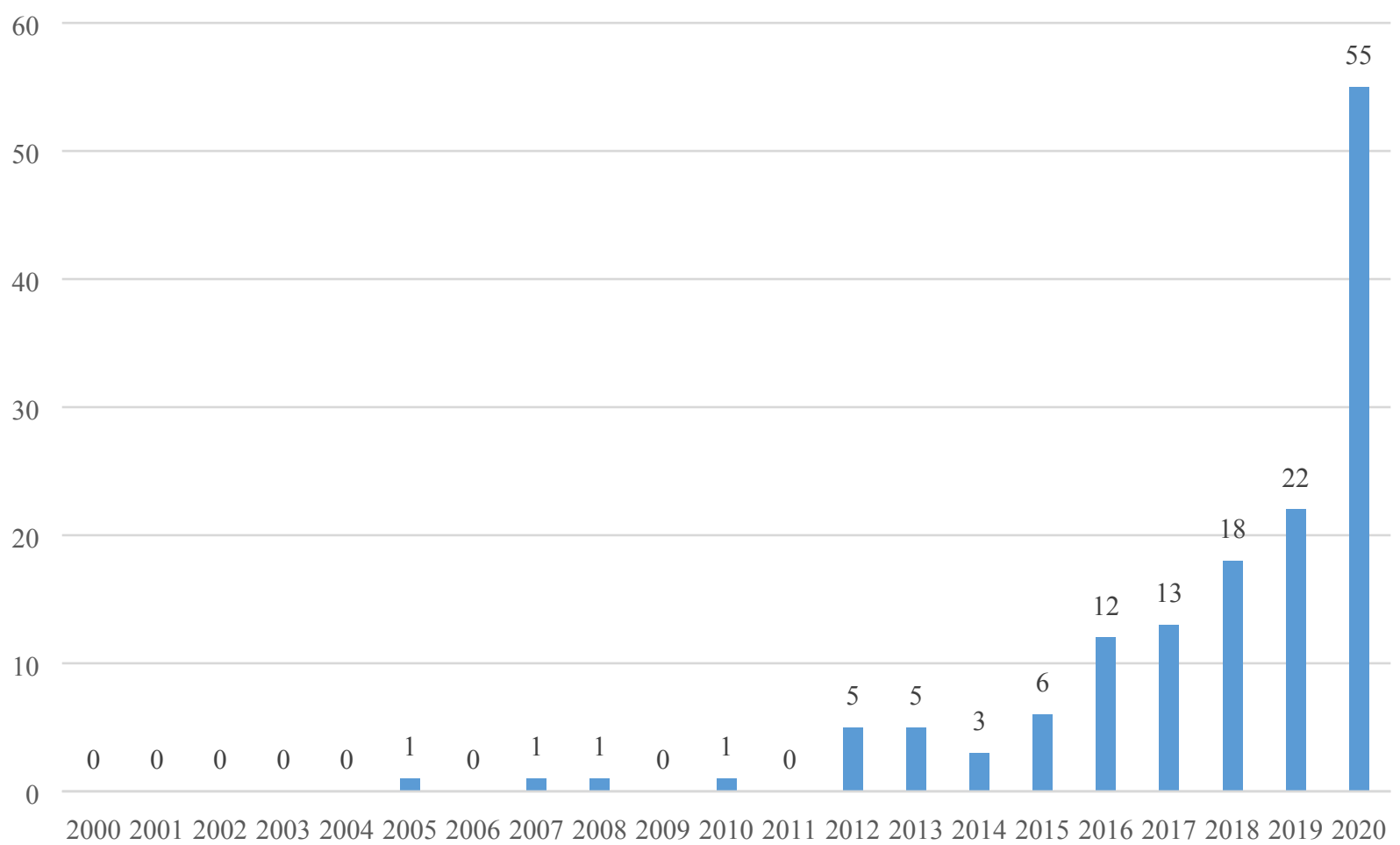

Figure 4. Distribution by year 


\begin{tabular}{|c|c|}
\hline Focused areas & Journal title (Number of articles) \\
\hline (15 journals -42 articles) & $\begin{array}{l}\text { Sustainability (12); Journal of Cleaner Production (6); Journal of } \\
\text { Business Ethics (5); Journal of Sustainable Tourism (4); Corporate } \\
\text { Social Responsibility and Environmental Management (3); Social } \\
\text { Responsibility Journal (3); Agroecology and Sustainable Food } \\
\text { Systems (1); Asian Journal of Business Ethics (1); Corporate } \\
\text { Governance: The International Journal of Business in Society (1); } \\
\text { Entrepreneurship and Sustainability Issues (1); Global Social } \\
\text { Policy (1); International Journal of Business and Society (1); } \\
\text { International Journal of Business Governance and Ethics (1); Issues } \\
\text { in Social \& Environmental Accounting (1); Journal of } \\
\text { Occupational and Environmental Hygiene (1); }\end{array}$ \\
\hline $\begin{array}{c}\text { Management and } \\
\text { Organisational Studies } \\
\text { (21 journals - } \mathbf{3 8} \text { articles) }\end{array}$ & $\begin{array}{l}\text { Management Science Letters (11); International Journal of } \\
\text { Contemporary Hospitality Management (2); Asia Pacific Business } \\
\text { Review (2); Asia-Pacific Journal of Business Administration (2); } \\
\text { Cogent Business \& Management (2); Journal of Organizational } \\
\text { Change Management (2); The Learning Organization (2); } \\
\text { Uncertain Supply Chain Management (2); Asian Academy of } \\
\text { Management Journal (1); International Journal of Recent Advances } \\
\text { in Organizational Behavior \& Decision Sciences (1); Journal of } \\
\text { Small Business Management (1); Management (1); Management } \\
\text { (France) (1); Polish Journal of Management Studies (1); Academy } \\
\text { of Management Journal (1); Industrial Engineering and } \\
\text { Management Systems (1); International Journal of Logistics } \\
\text { Management (1); International Journal of Public Sector } \\
\text { Management (1); Journal of Hospitality and Tourism Management } \\
\text { (1); Knowledge Management Research and Practice (1); Team } \\
\text { Performance Management: An International Journal (1) }\end{array}$ \\
\hline $\begin{array}{l}\text { Finance, Accounting, and } \\
\text { Economics } \\
\text { (19 journals }-31 \text { articles) }\end{array}$ & $\begin{array}{l}\text { Journal of Asian Finance, Economics and Business (11); } \\
\text { Accounting (3); Academy of Accounting and Financial Studies } \\
\text { Journal (1); Cogent Economics \& Finance (1); DLSU Business and } \\
\text { Economics Review (1); Emerging Markets Finance and Trade (1); } \\
\text { European Economic Review (1); International Journal of Energy } \\
\text { Economics and Policy (1); International Journal of Financial } \\
\text { Research (1); Journal of Applied Economic Sciences (1); Journal of }\end{array}$ \\
\hline
\end{tabular}




\begin{tabular}{|c|c|}
\hline & $\begin{array}{l}\text { Risk and Financial Management (1); Meditari Accountancy } \\
\text { Research (1); Pacific Accounting Review (1); International Journal } \\
\text { of Applied Business and Economic Research (1); Socio-Economic } \\
\text { Review (1); Tourism Economics (1); UTCC International Journal } \\
\text { of Business \& Economics (1); WSEAS Transactions on Business } \\
\text { and Economics (1); Environment and Development Economics (1) }\end{array}$ \\
\hline $\begin{array}{c}\text { Other fields } \\
\text { (19 journals }-21 \text { articles) }\end{array}$ & $\begin{array}{l}\text { Clinical Governance: An International Journal (2); International } \\
\text { Journal of Entrepreneurship (1); Journal of Development Studies } \\
\text { (1); Journal of International Studies (1); Journal of International } \\
\text { Business Research (1); Politics \& Society (1); International Journal } \\
\text { of Emerging Markets (1); Benchmarking: An International Journal } \\
\text { (1); British Food Journal (1); British Journal of Industrial Relations } \\
\text { (1); Gestion } 2000 \text { (1); Intangible Capital (1); International Journal } \\
\text { of Health Care Quality Assurance (1); Personnel Review (1); } \\
\text { Processes (1); Service Business (1); Societies (1); Journal of Asia- } \\
\text { Pacific Business (2); Journal of Business Research (1) }\end{array}$ \\
\hline $\begin{array}{l}\text { Marketing and } \\
\text { Communication }\end{array}$ & $\begin{array}{l}\text { International Journal of Pharmaceutical and Healthcare Marketing } \\
\text { (2); Marketing Intelligence and Planning (2); Academy of } \\
\text { Marketing Studies (1); Corporate Communications (1); Corporate } \\
\text { Reputation Review (1); Journal of International Consumer } \\
\text { Marketing (1); Journal of Pharmaceutical and Healthcare } \\
\text { Marketing (1); Journal of Strategic Marketing (1); Public Relations } \\
\text { Review (1) }\end{array}$ \\
\hline
\end{tabular}

Table 1. Distribution by journals

\begin{tabular}{|l|c|}
\hline Industry & No of articles \\
\hline General - Cross-industry & $61(43 \%)$ \\
\hline Textiles, Garment, and Footwear & $17(12 \%)$ \\
\hline Tourism and Hospitality & $14(10 \%)$ \\
\hline Healthcare & $12(8 \%)$ \\
\hline
\end{tabular}




\begin{tabular}{|l|c|}
\hline Food and Beverage & $11(8 \%)$ \\
\hline Banking & $6(4 \%)$ \\
\hline Software & $4(3 \%)$ \\
\hline Logistics & $3(2 \%)$ \\
\hline $\begin{array}{l}\text { Other industries, including Automobile, Creative, Energy, FMCG, Construction, } \\
\text { PR, Supermarket (Retail), Chemical, Mining, and Aviation }\end{array}$ & $15(10 \%)$ \\
\hline
\end{tabular}

Table 2. Distribution by industry

\begin{tabular}{|c|c|c|c|}
\hline \multicolumn{2}{|c|}{ Empirical research } & \multicolumn{2}{c|}{ Theoretical research } \\
\hline Quantitative & 94 & Non-Normative & 3 \\
\hline Qualitative & 22 & Normative & \\
\hline Mixed & 24 & & 3 \\
\hline Total & 140 & Total & \\
\hline
\end{tabular}

Table 3. The nature of CSR in Vietnam research, 2000-2020 


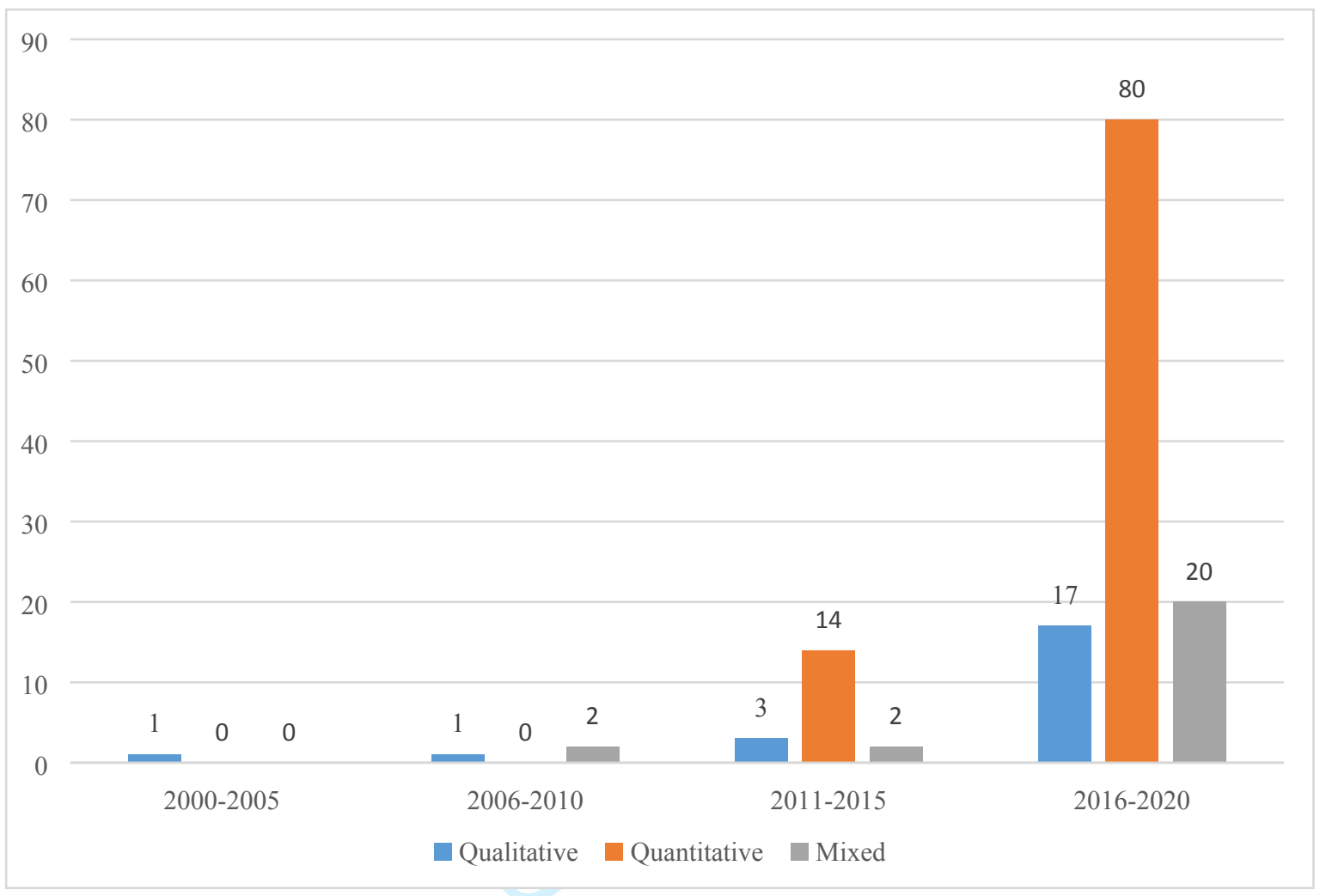

Figure 5. The changes in methodologies among empirical articles, 2000-2020

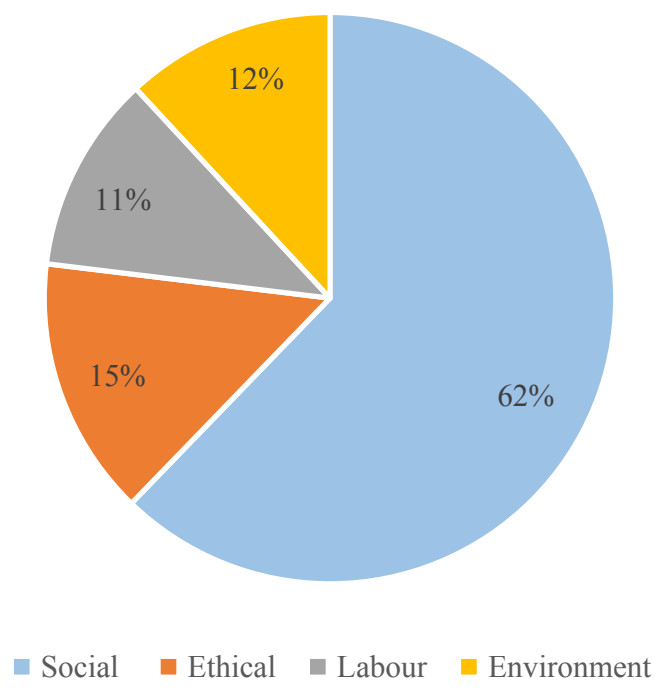

Figure 6. Dominant CSR themes 


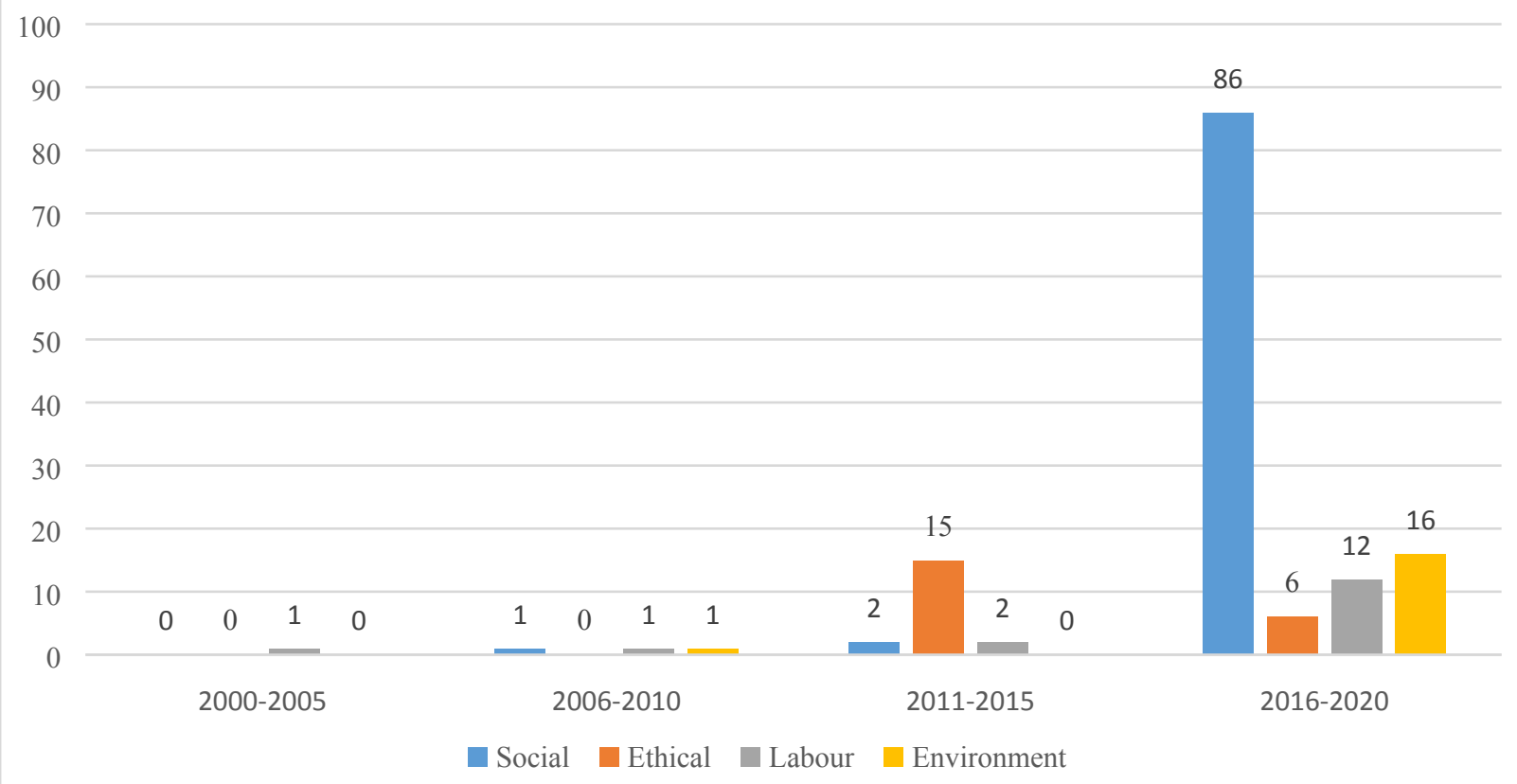

Figure 7. Dominant CSR themes, 2000-2020

\begin{tabular}{|c|c|c|c|c|c|}
\hline Argumentative & Analytical & $\begin{array}{c}\text { Compare and } \\
\text { Contrast }\end{array}$ & $\begin{array}{c}\text { Cause and } \\
\text { Effect }\end{array}$ & Report & Interpretive \\
\hline $2(1 \%)$ & $10(7 \%)$ & $5(3 \%)$ & $110(77 \%)$ & $2(1 \%)$ & $14(10 \%)$ \\
\hline
\end{tabular}

Table 4. Dominant objectives in CSR in Vietnam articles, 2000-2020

\begin{tabular}{|l|l|l|}
\hline Theoretical lens & No of articles & Percentage \\
\hline Single theory & 46 & $33 \%$ \\
\hline Multi theories & 39 & $30 \%$ \\
\hline Not specified & 58 & $37 \%$ \\
\hline
\end{tabular}

Table 5. Categories of theoretical frameworks

\begin{tabular}{|l|l|}
\hline Name of the theory & No of articles \\
\hline Stakeholder theory & 37 \\
\hline Agency theory & 15 \\
\hline Signaling theory & 9 \\
\hline
\end{tabular}




\begin{tabular}{|l|l|}
\hline Institutional theory & 8 \\
\hline Social Identity theory & 7 \\
\hline Legitimacy theory & 6 \\
\hline Theory of Reasoned Action & 6 \\
\hline Resource-based theory & 5 \\
\hline Lewin's field theory & 4 \\
\hline Schwartz's (1992) value theory & 4 \\
\hline Social exchange theory & 4 \\
\hline Conservation of Resources (COR) theory & 3 \\
\hline Self-consistency theory & 3 \\
\hline Social capital theory & 3 \\
\hline Structural holes theory & 3 \\
\hline Theory of Planned Behavior & 3 \\
\hline Contingency theory & 2 \\
\hline Slack Resource Theory & 2 \\
\hline
\end{tabular}

Table 6. Dominant theories 


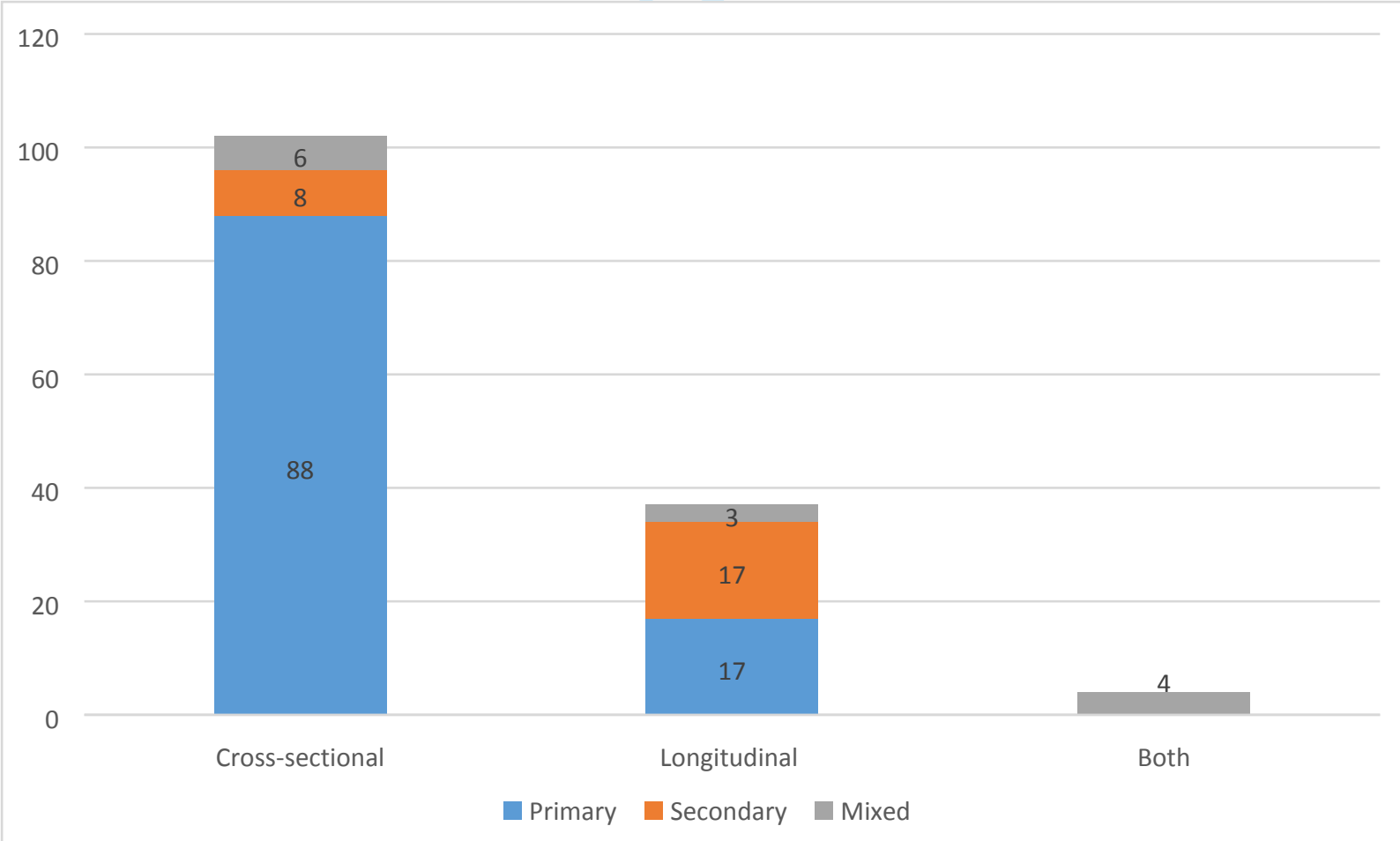

Figure 9. Nature and source of data in CSR in Vietnam articles, 2000-2020

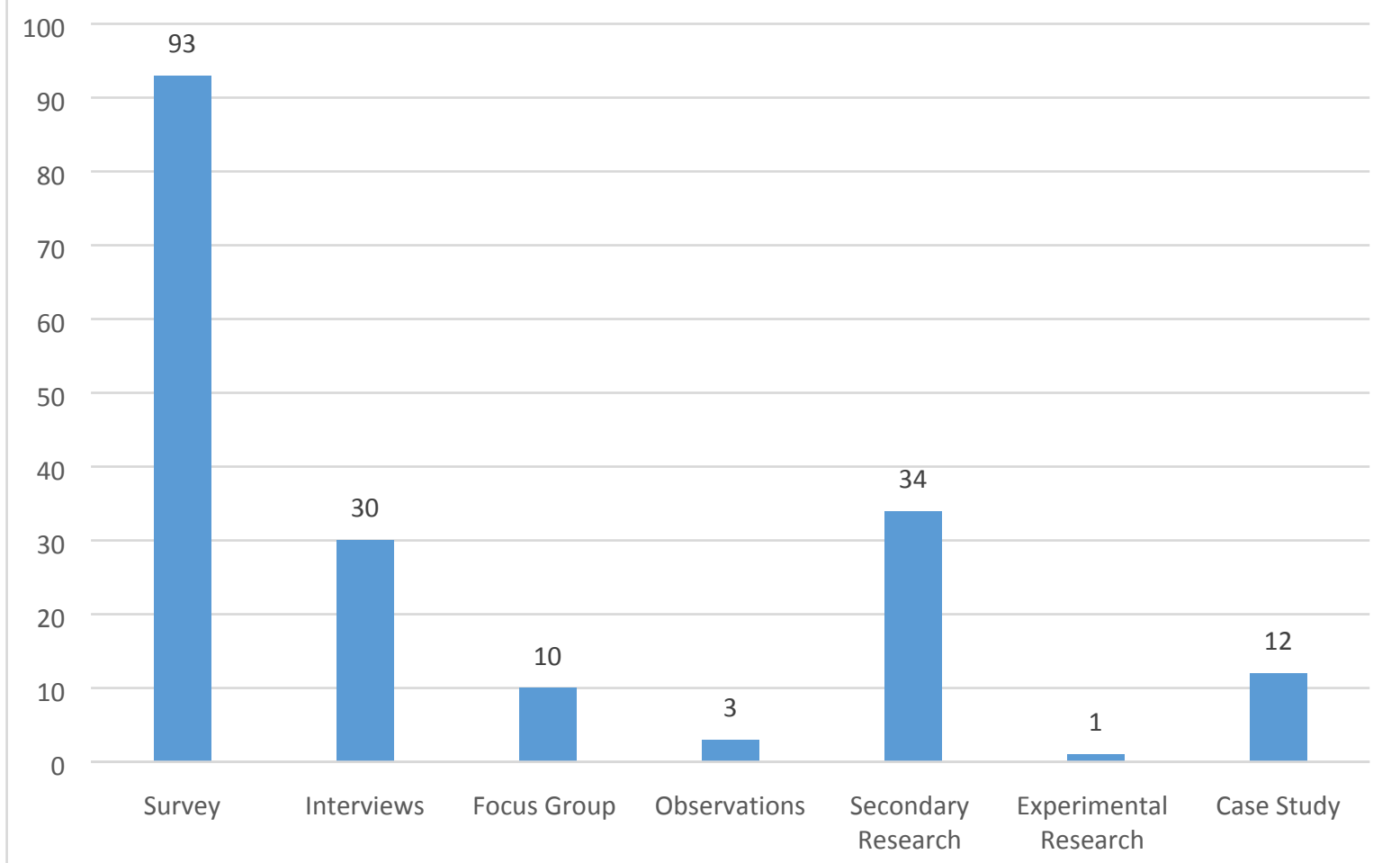

Figure 8. Dominant data collection method 


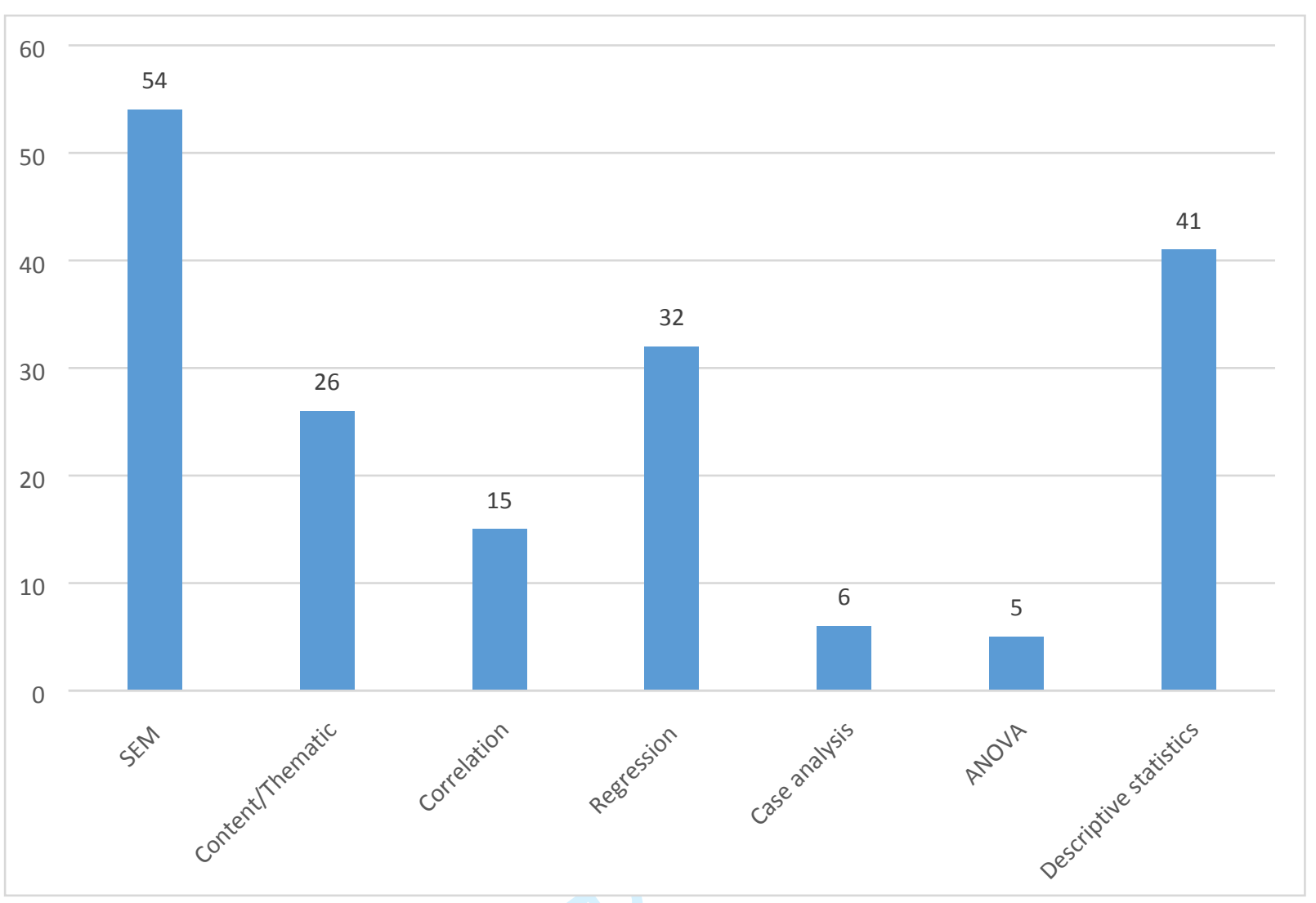

Figure 10. Dominant data analysis techniques 
Corporate Social Responsibility in Vietnam: Systematic review of research and future directions.

Nguyen, M

2021-08-02

http://hdl.handle.net/10179/16558

22/04/2023 - Downloaded from MASSEY RESEARCH ONLINE 